\title{
Revision of Nearctic Stylogaster (Diptera: Conopidae)
}

\author{
Trevor O. Burt, ${ }^{1}$ Jeffrey H. Skevington, Leonardo Rocha
}

\begin{abstract}
Nearctic Stylogaster Macquart (Diptera: Conopidae) species concepts are revised. We provide redescriptions of S. biannulata (Say) and S. neglecta Williston, description of S. beresfordi new species, an illustrated key to species, range maps, and ecological data. Stylogaster beresfordi ranges from southern Mexico to southern New Mexico, United States of America. DNA barcode data are provided with neighbour-joining and Bayesian analyses and relationships of the three species are discussed. We hypothesise that $S$. neglecta and $S$. beresfordi are sister taxa, while $S$. biannulata is in a different clade.
\end{abstract}

\section{Introduction}

Stylogaster Macquart (Diptera: Conopidae) is a diverse genus of parasitoid flies in the family Conopidae (Camras and Parrillo 1985). They are most prevalent in the Neotropical and Afrotropical regions and until recently only two species were known to inhabit the Nearctic Region, S. biannulata (Say) and S. neglecta Williston (Camras and Parrillo 1985). The range of these two species extends from southern Ontario, Canada to Mexico (Camras and Parrillo 1985). Though sharing much of the same habitat and appearing morphologically similar, they are not particularly closely related according to molecular and morphological analyses (Gibson and Skevington 2013; Gibson et al. 2013).

These two species are most easily distinguished from each other by examination of the antenna. In S. neglecta the flagellum is nearly twice as long as the pedicel, while in $S$. biannulata the flagellum and pedicel are about equal length. Additionally, the abdomens of females of both species are distinctive; $S$. biannulata is more stout and short, while S. neglecta is longer and more slender (Camras and Parrillo 1985).

Stylogaster has a parasitoid life history with females injecting eggs into a variety of hosts, including crickets, cockroaches (Kotrba 1997; Woodley and Judd 1998), and possibly calyptrate Diptera (Smith 1967; Couri and Pont 2006; Couri and Silva Barros 2010). The latter are suspected to be accidental ovipositions, as larvae have not been reared from flies (Stuke 2012). Many Stylogaster species in Africa and the Neotropics are facultative or obligate army ant followers (Bequaert 1922; Aldrich 1930; Lopes 1937; Rettenmeyer 1961). The flies occur in diversity and numbers around the leading edge of ant swarms where they attack fleeing Orthoptera (personal observation).

Kotrba (1997) explored the possible methods of egg delivery and concluded that it is most likely that the eggs are stabbed into the host abdomen and are held there by elaborate barbs found on the eggs. Lopes (1937) first described the eggs of Stylogaster and noted that many of the eggs revealed speciesspecific features. As a result, the eggs of all three Nearctic species are described and illustrated below.

Received 20 December 2013. Accepted 15 April 2014. First published online 3 July 2014.

T.O. Burt, ${ }^{1}$ J.H. Skevington, Canadian National Collection of Insects, Arachnids and Nematodes, Agriculture and Agri-Food Canada, 960 Carling Ave., Ottawa, Ontario, Canada K1A 0C6; and Department of Biology, Carleton University, 209 Nesbitt Building, Ottawa, Ontario, Canada K1S 5B6

L. Rocha, Canadian National Collection of Insects, Arachnids and Nematodes, Agriculture and Agri-Food Canada, 960 Carling Ave., Ottawa, Ontario, Canada K1A 0C6; and Museu Nacional, Universidade Federal do Rio de Janeiro, Quinta da Boa Vista, s/no., 20940-040, São Cristóvão, Rio de Janeiro, Brazil; and Instituto Federal de Educação, Ciência e Tecnologia do Rio de Janeiro, Rua Dr. José Augusto Pereira dos Santos, s/no., 24425-005, Neves, São Gonçalo, Rio de Janeiro, Brazil

${ }^{1}$ Corresponding author (e-mail: trevburt@gmail.com).

Subject editor: Bradley Sinclair

doi:10.4039/tce.2014.39

http://zoobank.org/urn:lsid:zoobank.org:pub:FD1D553A-796E-4F58-9CC3-A262B5ADCF5F 
When not attending army ant swarms, Stylogaster adults may typically be found hovering over paths in forest understorey or nectaring on small white or yellow flowers such as fennel (Foeniculum vulgare Miller (Apiaceae)), mints (Lamiaceae), and daisies (Asteraceae) (Smith and Peterson 1987). In parts of their range where there are no army ants, these are typically the only places to find these flies. They are relatively common but can be hard to spot (personal observation).

\section{Materials and methods}

Specimens were obtained from the following collections: American Museum of Natural History, New York, New York, United States of America (AMNH); Canadian National Collection of Insects, Arachnids, and Nematodes, Ottawa, Ontario, Canada (CNC); the University of Guelph Insect Collection, Guelph, Ontario, Canada (DEBU); the Los Angeles County Museum of Natural History, Los Angeles, California, United States of America (LACM); and the Museum of Comparative Zoology, Cambridge, Massachusetts, United States of America (MCZ). Morphological terminology follows Cumming and Wood (2009) and Gibson et al. (2013). Preliminary identifications relied on the key provided by Camras and Parrillo (1985).

Exemplar specimens were photographed with a Canon 50D EOS Digital Camera with an MP-E $65 \mathrm{~mm}$ macro lens (Canon Canada Inc., Mississauga, Ontario, Canada) and images were then stacked using Zerene Stacker Version 1.04 (Zerene Systems, Richland, Washington, United States of America). These images were further manipulated using Photoshop CS4 software (Adobe Systems Incorporated, San Jose, California, United States of America). Figure plates were prepared in Adobe Illustrator CS4 (Adobe Systems Incorporated). Illustrations of specimens were made by T.O.B., and were based on both lateral photographs and specimens under a dissecting scope. The microscope used was a Nikon SMZ1500 with a HI-150 High Intensity Illuminator (Nikon Canada Inc., Mississauga, Ontario, Canada).

Genitalia were excised by removing the whole abdomen, placing them in standard $1.5 \mathrm{~mL}$ Eppendorf tubes (Eppendorf Canada, Mississauga, Ontario, Canada) and immersing them in $95 \%$ lactic acid for no less than four hours on a $95^{\circ} \mathrm{C}$ dry bath incubator (Fisher Scientific, Toronto, Ontario,
Canada). Macerated abdomens were then placed on a glass depression slide and immersed in glycerin for dissection. The genitalia were then separated from the abdomen for comparison under the dissecting scope and were ultimately stored in genitalia vials with the specimens. Drawings were made of the genitalia of exemplar males, females, and eggs. All specimens examined were labelled with unique voucher numbers using the format CNC Diptera 12345 or Jeff Skevington Specimen \#12345 (shortened to $\mathrm{CNCD} n$ and JSSn throughout the text). These numbers are cited in the material examined sections and figure captions for illustrations to allow for repeatability of the research.

Molecular methods and analysis follow Skevington and Thompson (2012). Genetic work was carried out at the molecular laboratories of the CNC in Ottawa, Ontario, Canada and at University of Guelph, Guelph, Ontario, Canada. The resultant sequences, as well as images and related data, can be accessed through the Barcode of Life Data Systems (BOLD) (http://www.barcodinglife.org/) in the public data set "Nearctic Stylogaster (NESTY)" (http://www.boldsystems.org/views/ projectmenu.php?\&). In addition, all sequences were deposited in GenBank (Table 1).

No insertions or deletions exist in the COI data set so alignment was unambiguous. Phenetic analyses were performed with PAUP* (Swofford 2001). Neighbour-joining was used to explore species concepts for all 35 ingroup taxa. Bayesian methods were used with a reduced data set (one exemplar per species) for creating phylogenetic hypotheses. Exemplars from all four other conopid subfamilies were used as outgroups for analyses (Dalmannia pacifica Banks, Myopa clausa Loew, Physocephala burgessi (Williston), and Zodion obliquefasciatum (Macquart)). For Bayesian Analysis, models of evolution were determined based on the Akaike Information Criterion using ModelTest 3.7 (Posada and Crandall 1998). Bayesian analyses were conducted using MrBayes 3.1.2 (Ronquist and Huelsenbeck 2003) with a Markov Chain Monte Carlo method. Four chains (three hot, one cold) were run simultaneously for 10000000 generations. Trees were sampled every 1000 generations and each simulation was run twice. Following the discard of the first 1000 samples as burn-in, 9000 samples were used for each simulation to generate a majority-rule consensus tree and posterior probabilities for each node. Analysis was 
Table 1. List of taxa with specimen data used in neighbour-joining tree and Bayesian analysis.

\begin{tabular}{|c|c|c|c|c|}
\hline Species & Unique identifier & Genbank number & Country - state/province & Deposition \\
\hline S. banksi & CNCD19903 & KJ637696 & Costa Rica - Guanacaste & $\mathrm{CNC}$ \\
\hline S. beresfordi & CNCD195998 & KF715066 & United States of America - New Mexico & $\mathrm{CNC}$ \\
\hline S. beresfordi & CNCD199773 & KJ637700 & United States of America - New Mexico & $\mathrm{CNC}$ \\
\hline S. beresfordi & CNCD199801 & KJ637699 & United States of America - New Mexico & CNC \\
\hline S. beresfordi & CNCD199803 & KJ637698 & United States of America - New Mexico & $\mathrm{CNC}$ \\
\hline S. beresfordi & CNCD199810 & KJ637697 & United States of America - New Mexico & $\mathrm{CNC}$ \\
\hline S. beresfordi & CNCD199811 & KJ637701 & United States of America - New Mexico & $\mathrm{CNC}$ \\
\hline S. biannulata & JSS19827 & HM398255 & United States of America - Texas & $\mathrm{CNC}$ \\
\hline S. biannulata & CNCD28428 & KF715070 & Canada - Ontario & $\mathrm{CNC}$ \\
\hline S. biannulata & CNCD195993 & KF715069 & United States of America - Alabama & $\mathrm{CNC}$ \\
\hline S. biannulata & CNCD195994 & KF715068 & United States of America - Alabama & $\mathrm{CNC}$ \\
\hline S. breviventris & JSS19828 & HM398256 & Guyana - Upper Takutu/Essequi & $\mathrm{CNC}$ \\
\hline S. camrasi & JSS19881 & KJ637702 & Madagascar & $\mathrm{CNC}$ \\
\hline S. decorata & JSS19829 & HM398257 & Guyana - Upper Takutu/Essequi & $\mathrm{CNC}$ \\
\hline S. dispar & JSS19882 & HM398292 & French Guyana & $\mathrm{CNC}$ \\
\hline S. ethiopa & CNCD28430 & KJ637704 & Mexico - Chiapas & $\mathrm{CNC}$ \\
\hline S. fasciata & CNCD19928 & KJ637705 & Costa Rica - Alajuela & $\mathrm{CNC}$ \\
\hline S. frauci & JSS19830 & HM398258 & Australia - Queensland & $\mathrm{CNC}$ \\
\hline S. frauci & JSS19831 & HM398259 & Australia - Queensland & $\mathrm{CNC}$ \\
\hline S. frauci & $\mathrm{CNCD} 28495$ & KJ637706 & Australia - Queensland & $\mathrm{CNC}$ \\
\hline S. frontalis & CNCD28431 & KJ637707 & Uganda - Mpigi & $\mathrm{CNC}$ \\
\hline S. indistincta & CNCD19891 & KJ637710 & Costa Rica - Alajuela & $\mathrm{CNC}$ \\
\hline S. indistincta & JSS19892 & KJ637711 & Costa Rica - Alajuela & $\mathrm{CNC}$ \\
\hline S. indistincta & CNCD19910 & KJ637709 & Costa Rica - Alajuela & $\mathrm{CNC}$ \\
\hline S. indistincta & $\mathrm{CNCD} 28433$ & KJ637708 & Colombia - Valle del Cauca & $\mathrm{CNC}$ \\
\hline S. intermedia & CNCD19971 & KJ637713 & Costa Rica & $\mathrm{CNC}$ \\
\hline S. intermedia & CNCD19975 & KJ637712 & Costa Rica - Petén & $\mathrm{CNC}$ \\
\hline S. leonum & CNCD28434 & KJ637715 & Uganda - Mpigi & $\mathrm{CNC}$ \\
\hline S. longicornis & CNCD28435 & KJ637716 & Ecuador - Pastaza & $\mathrm{CNC}$ \\
\hline S. longispina & CNCD19972 & KJ637717 & Costa Rica & $\mathrm{CNC}$ \\
\hline S. magna & CNCD19956 & KJ637718 & Costa Rica & $\mathrm{CNC}$ \\
\hline S. neglecta & JSS18593 & KJ637722 & United States of America - Virginia & $\mathrm{CNC}$ \\
\hline S. neglecta & JSS18868 & KJ637721 & United States of America - Virginia & $\mathrm{CNC}$ \\
\hline S. neglecta & JSS19843 & HM398267 & United States of America - Virginia & $\mathrm{CNC}$ \\
\hline S. neglecta & CNCD195996 & KF715065 & Canada - Ontario & $\mathrm{CNC}$ \\
\hline S. neglecta & CNCD195997 & KF715067 & Canada - Ontario & $\mathrm{CNC}$ \\
\hline S. paradecorata & JSS18169 & KJ637723 & Guyana - Mazaruni-Potaro & DEBU \\
\hline S. peruviana & $\mathrm{CNCD} 28505$ & KJ637724 & Ecuador - Napo & $\mathrm{CNC}$ \\
\hline S. rectinervis & JSS19833 & KJ637725 & French Guiana - Régina & $\mathrm{CNC}$ \\
\hline S. sp. CR-01 & JSS19889 & KJ637727 & Costa Rica - Alajuela & $\mathrm{CNC}$ \\
\hline S. sp. CR-02 & JSS19848 & HM398272 & Costa Rica & $\mathrm{CNC}$ \\
\hline S. sp. CR-03 & JSS19904 & KJ637729 & Costa Rica - Alajuela & $\mathrm{CNC}$ \\
\hline S. sp. CR-04 & JSS19894 & KJ637726 & Costa Rica - Heredia & $\mathrm{CNC}$ \\
\hline S. sp. nov. MAD-01 & CNCD28498 & HM398239 & Madagascar - Mahajanga & $\mathrm{CNC}$ \\
\hline S. sp. nov. MAL-01 & CNCD28511 & KJ637728 & Malaysia - Selangor & $\mathrm{CNC}$ \\
\hline S. sp. nov. PNG-01 & CNCD28510 & KJ637730 & Papua New Guinea - Western & $\mathrm{CNC}$ \\
\hline S. sp. VEN-01 & JSS19825 & HM398254 & Venezuela - Lara & $\mathrm{CNC}$ \\
\hline S. stylata & JSS 18170 & KJ637734 & Brazil - Minas Gerais & DEBU \\
\hline S. stylata & CNCD28441 & KJ637733 & French Guiana - Régina & $\mathrm{CNC}$ \\
\hline S. tarsata & JSS18197 & KJ637736 & Costa Rica & $\mathrm{CNC}$ \\
\hline S. tarsata & JSS19893 & KJ637737 & Costa Rica - Alajuela & $\mathrm{CNC}$ \\
\hline S. tarsata & CNCD19973 & KJ637738 & Costa Rica & $\mathrm{CNC}$ \\
\hline S. tarsata & JSS19978 & KJ637735 & Costa Rica & $\mathrm{CNC}$ \\
\hline S. triannulata & CNCD19927 & KJ637739 & Costa Rica - Guanacaste & $\mathrm{CNC}$ \\
\hline S. westwoodi & JSS19836 & KJ637740 & Democratic Republic of Congo - Katanga & $\mathrm{CNC}$ \\
\hline S. westwoodi & CNCD28509 & KJ637741 & Uganda - Mpigi & $\mathrm{CNC}$ \\
\hline
\end{tabular}


conducted using the Cyberinfrastructure for Phylogenetic Research (Miller et al. 2010) and a cladogram was generated using Mesquite (Maddison and Maddison 2011).

\section{Results and discussion}

While testing species concepts for Nearctic conopids with mitochondrial DNA data (cytochrome oxidase $c$ subunit 1 ), we discovered a putative cryptic species within $S$. neglecta. Upon closer examination, we found subtle, stable morphological differences between this putative new species and $S$. neglecta. For example, the ocellar triangle and frontal vitta is always darker, almost black, in the new species, where it is rather pale, yellow to brown, in S. neglecta. Camras and Parrillo (1985) described the triangle as dull in $S$. neglecta. The scape of $S$. beresfordi new species is always darker than S. neglecta and shiny. Upon dissection of the male and female genitalia we found other differences between these species lending support to our hypothesis.

Separating S. neglecta and S. beresfordi from S. biannulata is trivial and can be done quickly by examination of the antennae. Male and female genitalia and eggs also differ considerably between these species. We provide species descriptions, illustrations and a dichotomous key to species of Nearctic Stylogaster below.

\section{Key to Nearctic Stylogaster}

1. Frontal vitta entirely black (Fig. 3A); pedicel and flagellum about equal in length (Fig. 3A); lighter species (pale yellow with darker orange brown areas on abdomen, and darker brown banding on hind tibia and distal end of femur through to tarsi) (Fig. 3F); little or no lateral maculation on the thorax (slightly darker maculation on anepisternum) (Fig. 3F); abdominal banding is fairly regular towards posterior (Fig. 3G); thorax dorsal maculation (black) forks into three distinct points at posterior (Fig. 3B); stylus (fused sternite 7) of female shorter and more robust than other Nearctic species with slight lateral ridge (Fig. 3E). Eastern North America

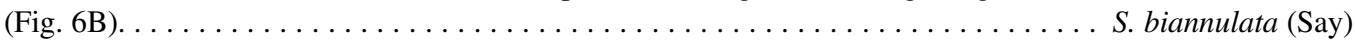

- Frontal vitta predominantly yellow (Figs. 4A, F) or pale brown (Fig. 2A, E) with black center; pedicel less than half the length of the flagellum (Figs. 2A, 4A); darker species (brownish yellow with darker brown areas on dorsal abdomen, and darker brown banding on hind tibia and distal end of femur through to tarsi) (Figs. 1A, 2E, 4F); darker lateral maculation on and about anepisternum (brown, almost black) (Figs. 2C, 4E); abdominal banding becomes gradually darker towards posterior in males (Figs. 2E, 4F), in females banding is often vague; thorax maculation (dark brownish black) does not fork, but is rather truncate (Fig. 4B); stylus (fused sternite 7) of female thin, smooth, long and slender without lateral ridge (Fig. 2 B) $\ldots \ldots \ldots \ldots \ldots$

2. Frontal vitta predominantly yellow with black ocellar triangle (Fig. 4A, F); scape pale (yellow); males with pale abdominal banding usually unbroken by darker median maculation (Fig. 4F), in females banding is somewhat lacking; lateral and ventral setulae on and near the first abdominal tergite usually black, though variably pale; male surstylus and postgonite both narrow, elongate (Fig. 5B). Eastern North America

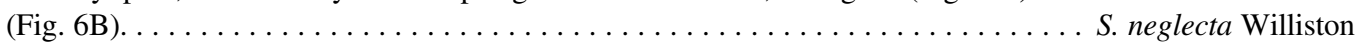

- Frontal vitta predominantly blackish brown with black ocellar triangle (Fig. 2A); scape darker (brownish yellow); males with pale abdominal banding broken by darker median maculation (Fig. 2E), in females banding is pale and darker brown; lateral and ventral setulae on and near the first abdominal tergite usually pale, though variably black; male surstylus and postgonite both broad, stubby (Fig. 5A). Southwestern North

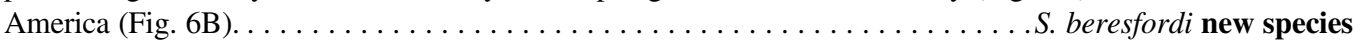

\section{Stylogaster beresfordi Burt, Skevington, and Rocha, new species}

(Figs. 1A-C, 2A-F, 5A, 6)

Material Examined: Holotype $o \hat{c}$, United States of America: New Mexico: Grant County,
14 miles North of Silver City, Cherry Creek Campground, $32.91334^{\circ} \mathrm{N}, 108.22667^{\circ} \mathrm{W}, 2256 \mathrm{~m}$, 16-19.viii.1999, J.E. O'Hara, Malaise trap, CNCD195998 (CNC). Paratypes: United States of America: Arizona: Santa Cruz county, Patagonia, $31.53^{\circ} \mathrm{N}, 110.57^{\circ} \mathrm{W}$, 5.viii.1995, 1 ㅇ, 13. 
viii.1995, 1ㅇ, 20.viii.1995, 10, 27.viii.1995, 1옹, B. Brown and E. Wilk. MT, LACM ENT 319810, 319811, 319812, 319813 (LACM); Oak Creek County, viii.1947, 1ð, RMB Bohart, LACM ENT 319805 (LACM). New Mexico: same location as holotype, 15-16.viii.1993, 10, 16-19.viii.1999, 3ơ, 18-19.viii.1999, 1, CNCD199772-4, 199801, 199803 (CNC); Manzano Mountains, 8 miles west Manzano, New Canyon Campground, $34.67167^{\circ} \mathrm{N}, 106.41^{\circ} \mathrm{W}, 2377 \mathrm{~m}, 21-23$. viii.1999, 30, 2o, J.E. O’Hara, Malaise trap, CNCD199802, 199810, 199811, 199812 (CNC).

Mexico: Chiapas: Yerba Bueno, Highway 195, $16.93651^{\circ} \mathrm{N}, 92.89683^{\circ} \mathrm{W}, 24 . v i .1969,1{ }^{\circ}$, B.V. Peterson, abdomen missing, CNCD199744 (CNC). Sinaloa: 15 miles West of El Palmito, 23.56142 ${ }^{\circ} \mathrm{N}, 105.83710^{\circ} \mathrm{W}, 1524 \mathrm{~m}, 20 . v i i .1964$, 10َ, W.R.M. Mason, CNCD199742 (CNC). Other material examined: United States of America: Arizona: Yavapai County, Bradshaw Ranger District, Prescott National Forest, Along Lynx Creek above Lynx Lake, $34.5298^{\circ} \mathrm{N}$, $112.3842^{\circ} \mathrm{W}, 1695 \mathrm{~m}, 12 . v i i .2013,10^{\star}, 1 \%$, D.D. Moll, photograph of male, sight record of female (Fig. 1C; BugGuide: http://bugguide.net/node/ view/826953/bgimage).

Etymology: $S$. beresfordi is named after Dr. David Beresford, an entomology professor at Trent University in Peterborough, Ontario, Canada, who is a dipterist specialising in biting flies and an important mentor of the senior author.

Diagnosis: Distinguished from S. biannulata by the subequal length of the flagellum and pedicel; the flagellum is nearly twice as long as the pedicel (Fig. 2A); the ocellar triangle and frontal vitta is always dark in colour (black or dark brown) (Figs. 2A, E), darker than in S. neglecta; lateral and ventral setae on first abdominal tergite are usually pale, though this is somewhat variable (generally black in S. neglecta); the male surstylus and postgonite are both broader and stubbier than in S. neglecta (Fig. 5A).

Description: Male: Body length 6-7 mm.

Head: Face pale yellow with faint silver microtomentum extending narrowly between eyes and frontal vitta, with six to seven black setae in a row along inside of each eye; facial carina sharp and narrow; ocellar triangle with rounded protruding ocellar protuberance bearing two long setae; two long setae just posterior to protuberance; frontal vitta and ocellar triangle shiny and dark, brownish black surrounded by dull and darker V-shaped area runs along inside of eyes above antenna; dorsal occiput with distinctive patches of silver microtomentum, and long white setulae; scape, pedicel and flagellum mainly yellow, with only slight brown darkening ventrally; arista wholly dark brown; flagellum twice length of pedicel; scape appears slightly darker than in S. neglecta; subtle light-coloured microtomentum on pedicel and flagellum.

Thorax: Laterally pale yellow with brown maculation on anepisternum and katepisternum; one long black seta on anepimeron next to one shorter seta variably present; single long pale seta on lateral prosternum; thorax dorsally longer than wide (Fig. 2E); dorsal anterior postpronutum paler with pale microtomentum and single long black seta; dorsal thorax mainly black with slightly lighter brown area posteriorly and two very faint dark brown median stripes; dorsal thorax covered with short setulae only on area of darker maculation; four long black setae (not including setae on postpronutum) fairly evenly spaced along each side of dorsal lateral edge of thorax posteriorly while two postallar callus setae closer together; scutellum dark brown to black with two long posterior black setae, lighter than rest of dorsal surface of thorax.

Legs: Coxae pale yellow with hind coxa slightly darker; front coxa with one to two short black setae among pale setae; hind coxa has one longer seta laterally with one to two more medioventrally; mid coxa with several short pale and sparse black setulae anteriorly; hind legs covered in short black setulae, fore and mid legs mainly covered in pale setulae with only a few darker setulae interspersed becoming more regularly dark after tibia; fore and mid femora pale yellow; hind femur pale yellow with three darker brown bands (Figs. 1A-C, 2C), final band appearing at junction with tibia; fore and mid tibiae and tarsi pale yellow with dark setulae, hind tibia mostly pale, becoming abruptly darker brown basally, colour extending to tarsi; hind tibia with three black basal spurs; fore and mid tibiae with single pale spur; tarsomere 2 about $3 / 4$ length of tarsomere 1 while tarsomere 3 is about $3 / 4$ length of tarsomere 2; tarsomere 4 and 5 equal to each other but each shorter than tarsomere 3 .

Wing: Costal vein covered in short setulae with one long black seta dorsobasally. 
Fig. 1. Stylogaster beresfordi new species. (A) Right lateral habitus drawing, male. Scale bar $=1 \mathrm{~mm}$; (B) right lateral habitus photograph, male; (C) right lateral habitus photograph, female. Photos: David Moll.
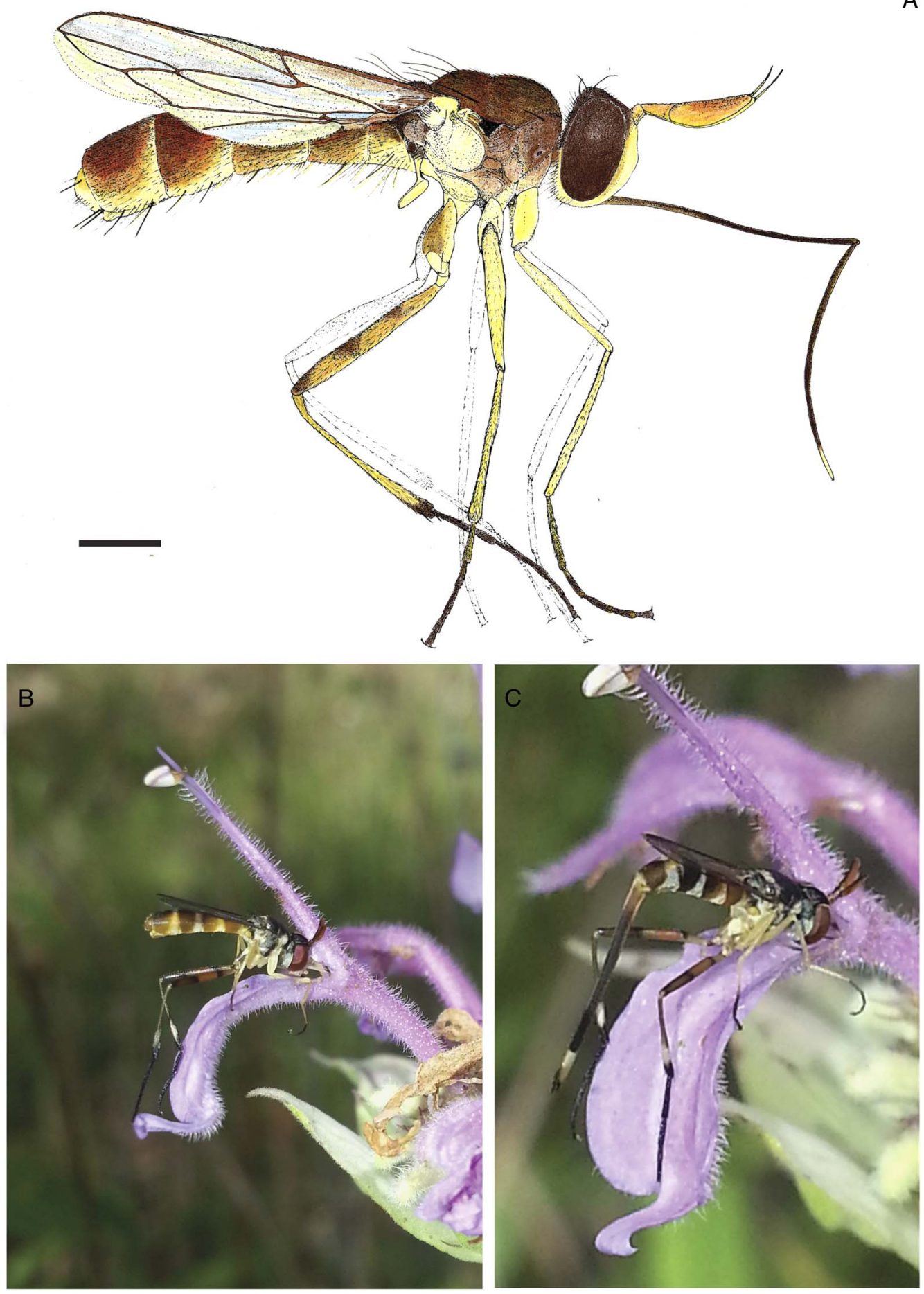
Fig. 2. Stylogaster beresfordi new species. (A) Dorsal head with antennae. Scale bar $=1.8 \mathrm{~mm}$; (B) left lateral habitus of abdominal ovipositor of female. Scale bar $=1 \mathrm{~mm}$; (C) right lateral habitus photograph CNCD 199772. Scale bar $=1 \mathrm{~mm}$; (D) right lateral of egg. Scale bar $=0.25 \mathrm{~mm}$; (E) dorsal habitus photograph CNCD 199772. Scale bar $=1 \mathrm{~mm}$; (F) left lateral habitus of female terminalia: cerc, cerci; lat l-st, lateral lobes of sternite 8; hyp, hypoproct. Scale bar $=1 \mathrm{~mm}$.

A

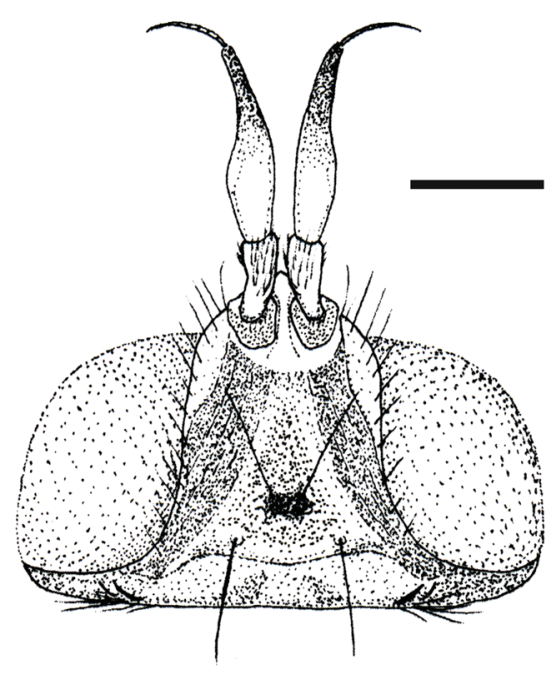

$\mathrm{D}$

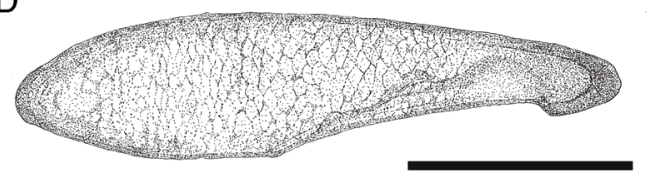

B

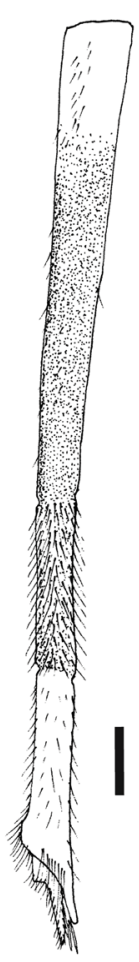

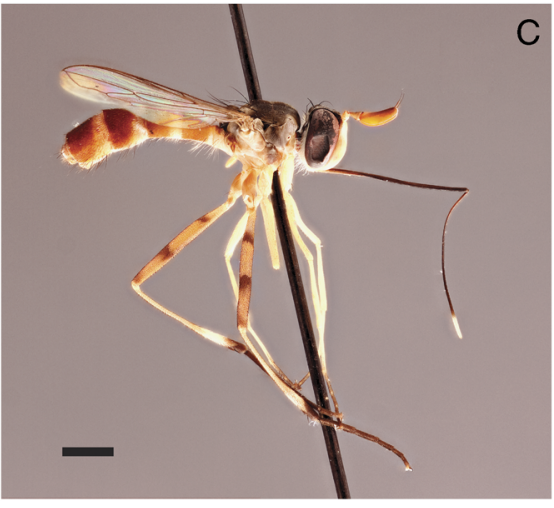

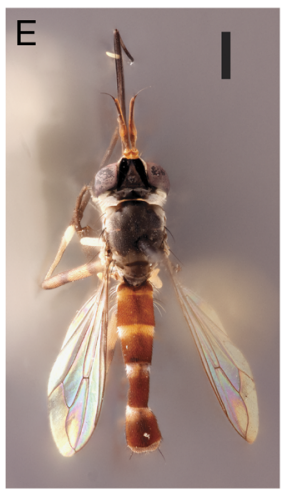

$\mathrm{F}$

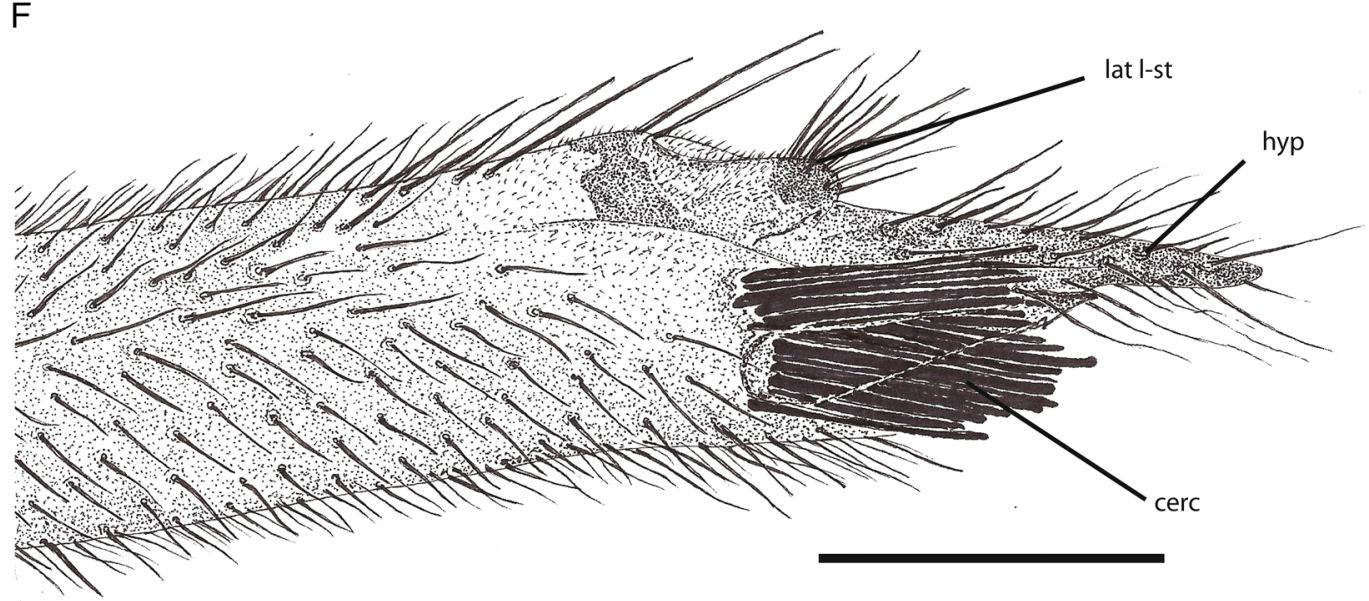

Abdomen: More bulbous posteriorly (Fig. 2G); tergites pale yellow with darker brown banding and faintly darker secondary banding within, only noticeable dorsally at posterior edge of each tergite, tergites 4 and 5 darker overall with yellow banding slightly interrupted dorsally by darker 
Fig. 3. Stylogaster biannulata. (A) Dorsal head with antennae. Scale bar $=1.8 \mathrm{~mm}$; (B) dorsal habitus of thorax. Scale bar $=1.8 \mathrm{~mm}$; (C) right lateral of egg. Scale bar $=0.25 \mathrm{~mm}$; (D) left lateral habitus of female terminalia: cerc, cerci; lat 1-st, lateral lobes of sternite 8; hyp, hypoproct. Scale bar $=1 \mathrm{~mm}$; (E) left lateral habitus of abdominal stylus of female. Scale bar $=1 \mathrm{~mm}$; (F) right lateral habitus photograph CNCD 195559. Scale bar $=1 \mathrm{~mm} ;(\mathrm{G})$ dorsal habitus photograph CNCD 195559. Scale bar $=1 \mathrm{~mm}$.

A

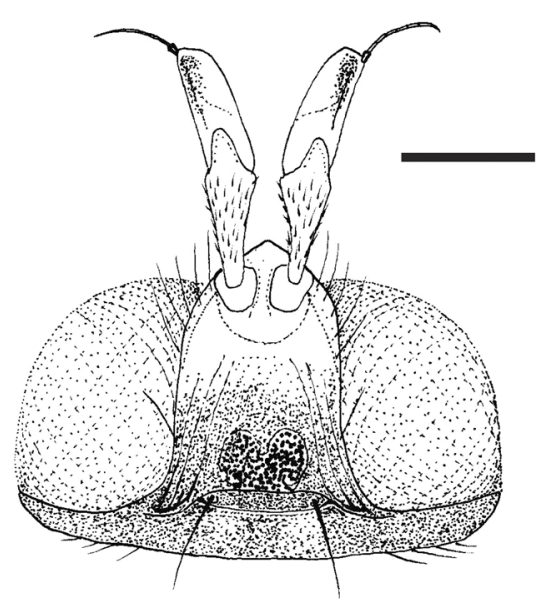

C

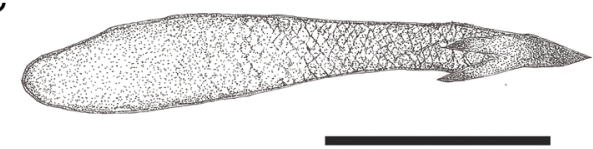

$\mathrm{D}$
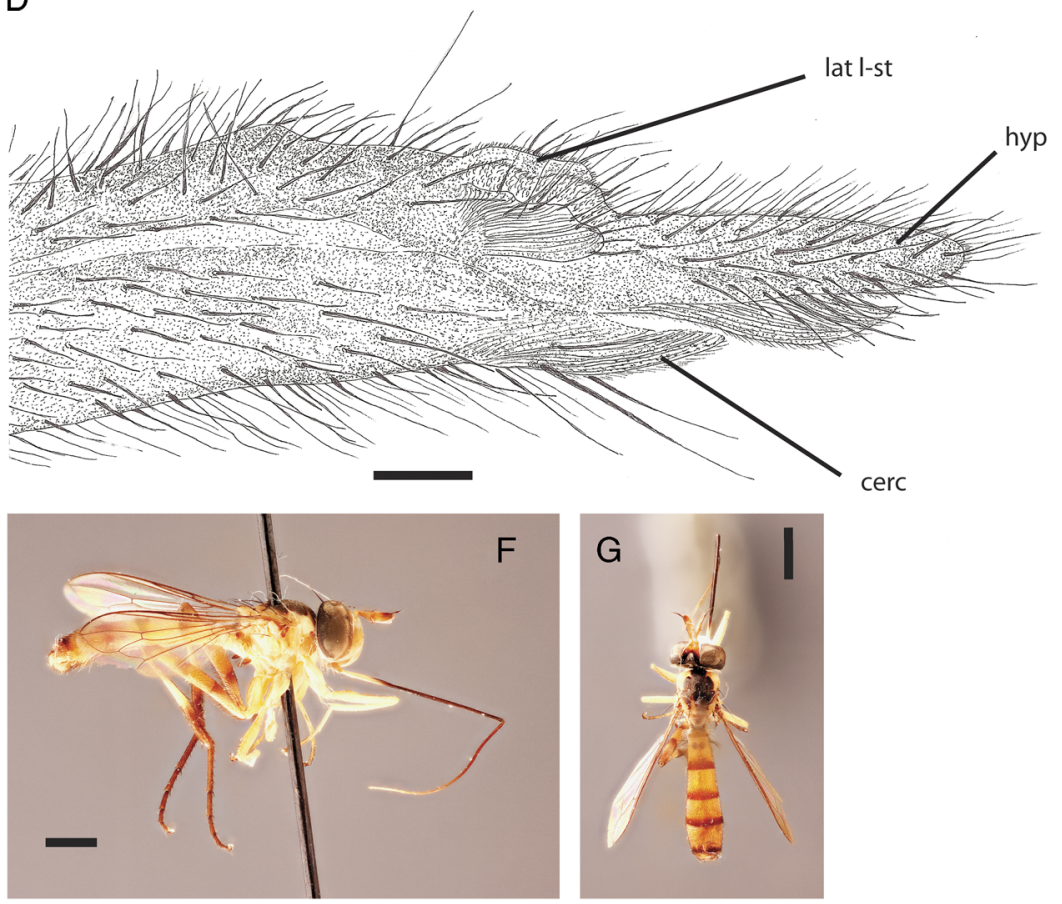

B

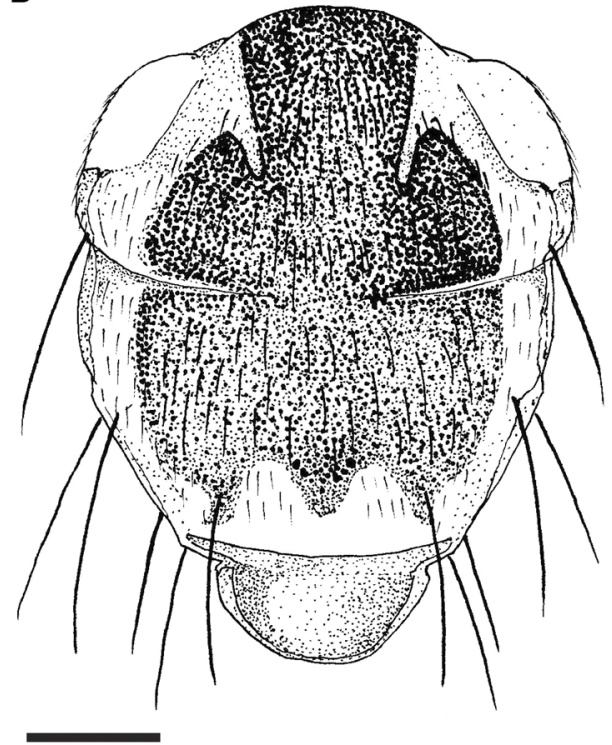

$E$

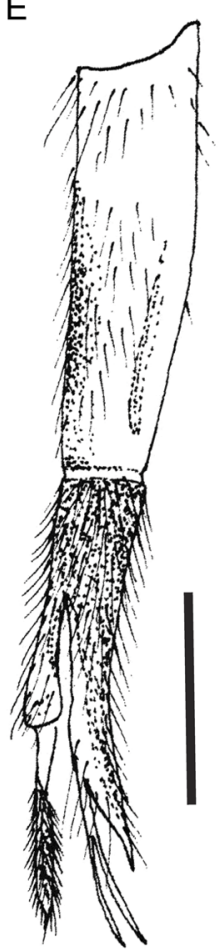


maculation; tergite 2 with most prominent darker band on and towards posterior edge; ventral sternites absent except for 5th, which bears sharp carina and reduced overall; abdomen entirely covered in short black setulae dorsally, laterally black setae alternate to paler yellow where maculation paler; lateral ventral edge of tergites have long pale setae interspersed with some black setae becoming mainly black towards the posteriorly; viewed dorsally, tergite with two long black setae extending posteriorly.

Genitalia: Epandrium bulbous, rounded, with two long, black posterior bristles amidst many black setulae; surstylus with two lobes: former with small black spines on inner face and black spines on outer face with concave groove basallaterally; latter lobe with black setae at base; cercus double-lobed, with one lobe somewhat clubbed, while other sharper distally; dorsally; cercus with many long black setae; hypandrium flat and elongate, appearing bulbous, and irregular with a short protruding lobe extending dorsally; postgonite somewhat elongate, bulbous and rounded basally, rather curled and cup-shaped with mixture of short setulae and black spines; phallus double-stranded, light brown and elongate (Fig. 5A); phallapodeme cylindrical and elongate, more bulbous distally; sperm pump only slightly smaller than epandrium, membranous; ejaculatory apodeme very rounded, teardropshaped.

Female: Similar to male, except banding less clear; ovipositor virtually indistinguishable from S. neglecta (Fig. 2B), twice as long as thorax and head combined; first 5 th of ovipositor pale yellow graduating to darker brown with last 5th pale yellow; setae of ovipositor sparse on darker areas becoming more regular towards posterior; setulae pale yellow to white on last 5th of tergite near terminalia.

Terminalia: Tergite 7 or stylus (segment 7) cylindrical, elongate and pale with sparse, short setae (Fig. 2B); tergite 8 cylindrical and $1 / 3$ as long as stylus with longer, coarser setae than stylus; tergite 9 short and fused dorsally just before lateral lobes of sternite 8, which are short and rounded with crop of long, bushy setulae; hypoproct arrow-shaped, short and moderately pointed with many long setae; cercus short, with very thick and long black spines, not extending to tip of hypoproct (Fig. 2F).
Egg: Anterior tip (nonmicropylar end) sharply pointed (Fig. 2D), highly sclerotised, with pair of ventral, posterior-facing (downward) spines or barbs, slightly shorter than in $S$. biannulata (S. biannulata egg, Fig. 3C); barbs often encased within thin translucent film; tip in shape of arrowhead or harpoon when viewed ventrally or dorsally; body elongate, cylindrical, becoming gradually more bulbous posteriorly (micropylar end), giving egg club-shaped appearance; longitudinal slit between pair of sclerotised barbs where eversible sac originates upon inflation; viewed laterally, anterior end appears rounded, or softened blade, egg body posteriorly clavate; under high magnification surface appears sculptured, scales-like, less defined or altogether absent towards anterior tip.

Hosts: Unknown, but presumably crickets and/or cockroaches as in other known Stylogaster (Smith and Cunningham-van Someren 1985; Woodley and Judd 1998).

Known distribution: Stylogaster beresfordi is a southwestern Nearctic species, occurring from SW New Mexico and SE Arizona south through Mexico, between 1238-2377 $\mathrm{m}$ in elevation (Fig. 6B).

Comments: Bayesian analayis of COI data for 35 species of Stylogaster shows S. beresfordi to be the sister species to S. neglecta (Fig. 7). Morphologically, the two species are very similar, differing only in small differences in male genitalia and colouration. DNA evidence strongly supports our hypothesis that $S$. beresfordi is a valid species. Six specimens were sequenced and differ by only $0.0-0.2 \%$ and cluster together in as a monophyletic lineage in a neighbour-joining tree (Fig. 8). The uncorrected pairwise genetic distance between $S$. beresfordi and $S$. neglecta is $3.6-4.2 \%$. The COI sequences are published in GenBank (Table 1).

\section{Stylogaster biannulata (Say)}

(Figs. 3A-G, 5B, 6)

Myopa biannulata Say, 1823: 81. Type locality: United States of America, Pennsylvania. Type depository: ANSP.

Myopa ?stylata Fabricius. Wiedemann 1830: 243; Röder 1892: 287.

Stylogaster ?stylatus (Fabricius). Macquart 1843: 175; Osten Sacken 1878: 140, 259. 
Fig. 4. Stylogaster neglecta. (A) Dorsal head with antennae. Scale bar $=1.8 \mathrm{~mm}$; (B) dorsal habitus of thorax. Scale bar $=1.8 \mathrm{~mm}$; (C) right lateral of egg. Scale bar $=0.25 \mathrm{~mm}$; (D) left lateral habitus of female terminalia: cerc, cerci; lat 1-st, lateral lobes of sternite 8; hyp, hypoproct. Scale bar $=1 \mathrm{~mm}$; (E) right lateral habitus photograph CNCD 79778. Scale bar $=1 \mathrm{~mm}$; (F) dorsal habitus photograph CNCD 79778. Scale bar $=1 \mathrm{~mm}$.

A

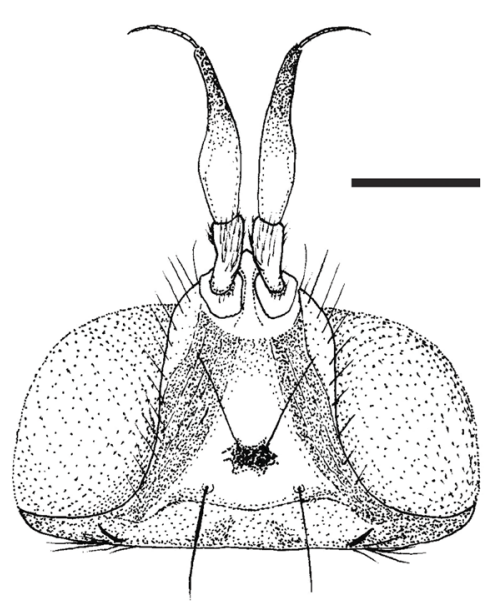

B

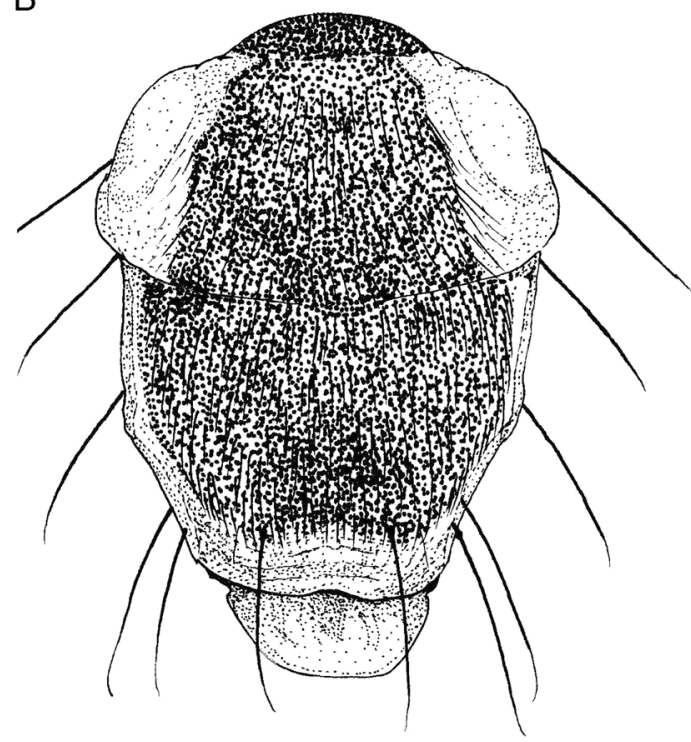

C

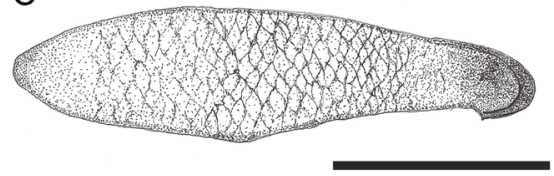

D
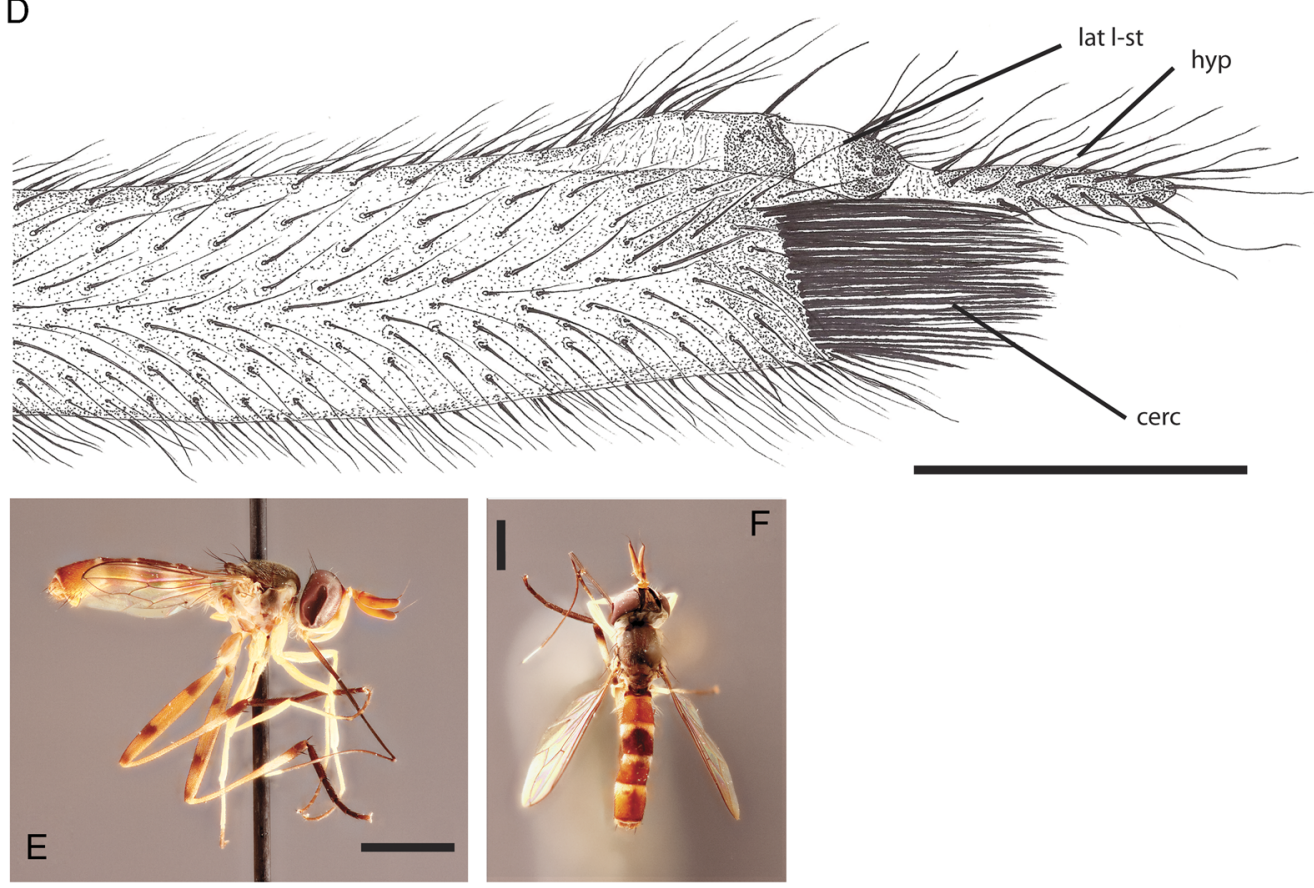
Fig. 5. Left lateral of male terminalia. (A) Stylogaster beresfordi; (B) Stylogaster neglecta: cerc, cerci; ej apod, ejaculatory apodeme; epand, epandrium; hyp, hypandrium; ph, phallus; phapod, phallapodeme; pgt, postgonite; spm pmp, sperm pump; sur surstylus. Scale bars $=0.25 \mathrm{~mm}$.

A

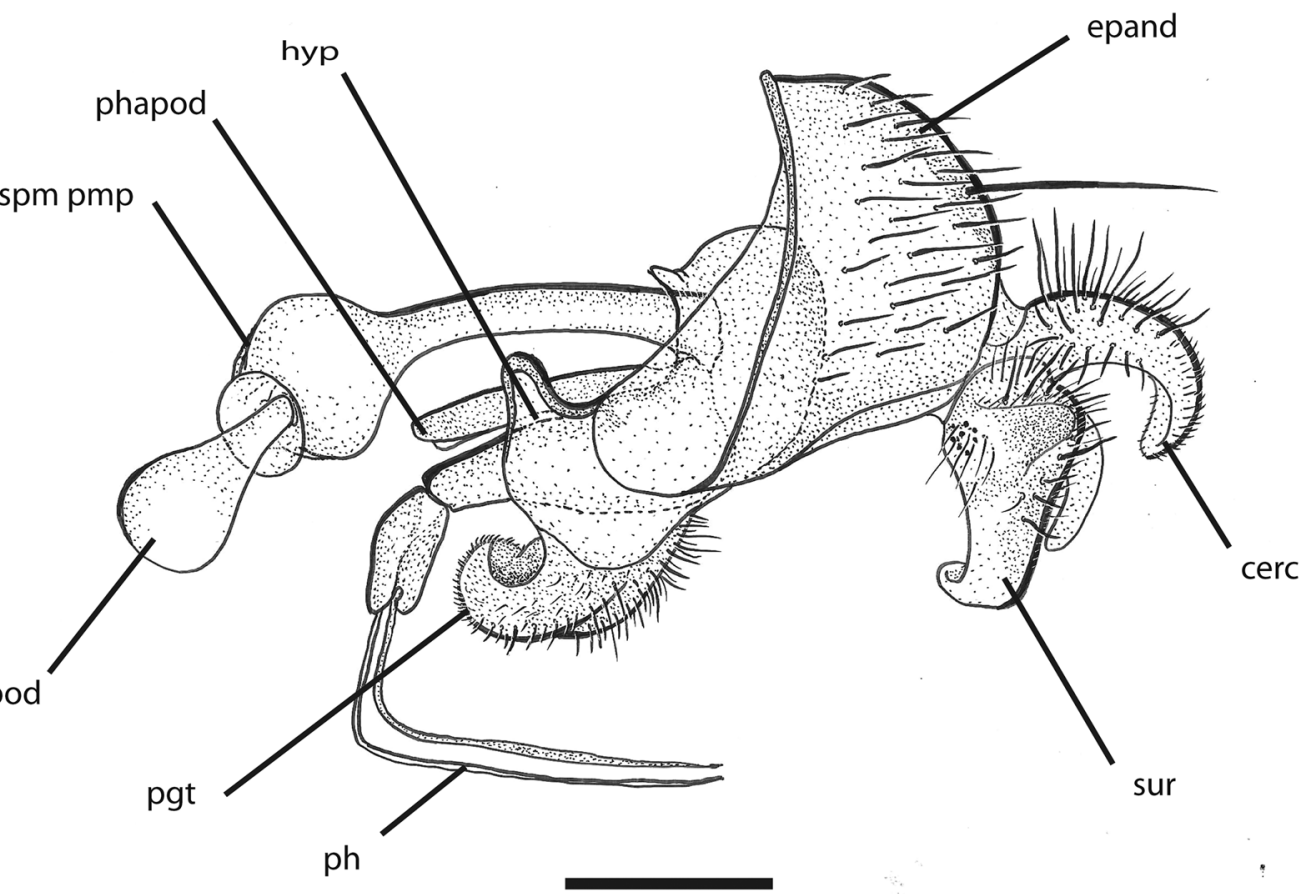

B

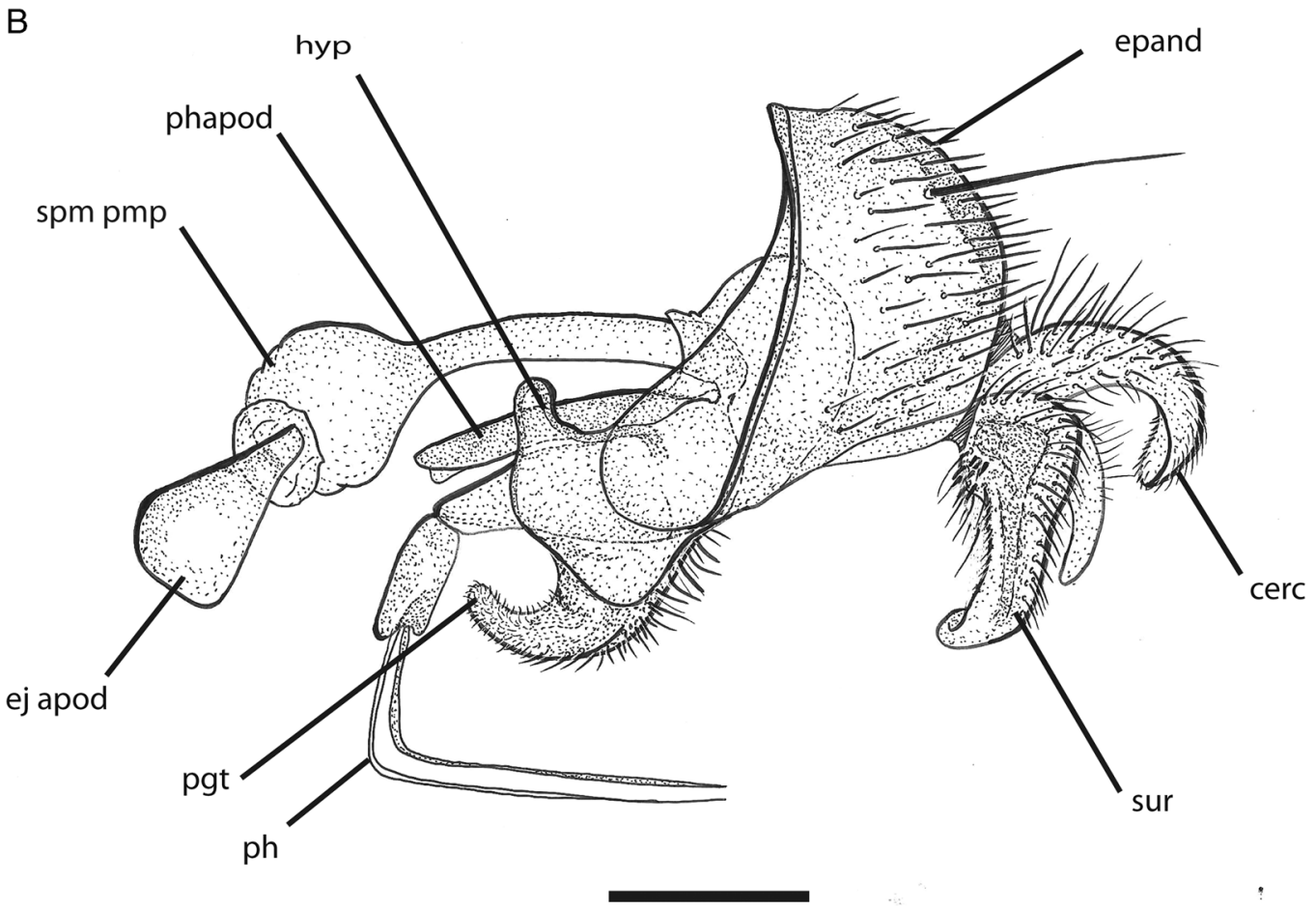


Fig. 6. (A) Left lateral of male genitalia of Stylogaster biannulata: cerc, cerci; ej apod, ejaculatory apodeme; epand, epandrium; hyp, hypandrium; ph, phallus; phapod, phallapodeme; pgt, postgonite; spm pmp, sperm pump; sur, surstylus. Scale bars $=0.25 \mathrm{~mm}$. (B) Range map; Stylogaster beresfordi $(\mathbf{\Lambda})$, Stylogaster biannulata $(\bullet)$, Stylogaster neglecta $(\mathbf{\square})$.
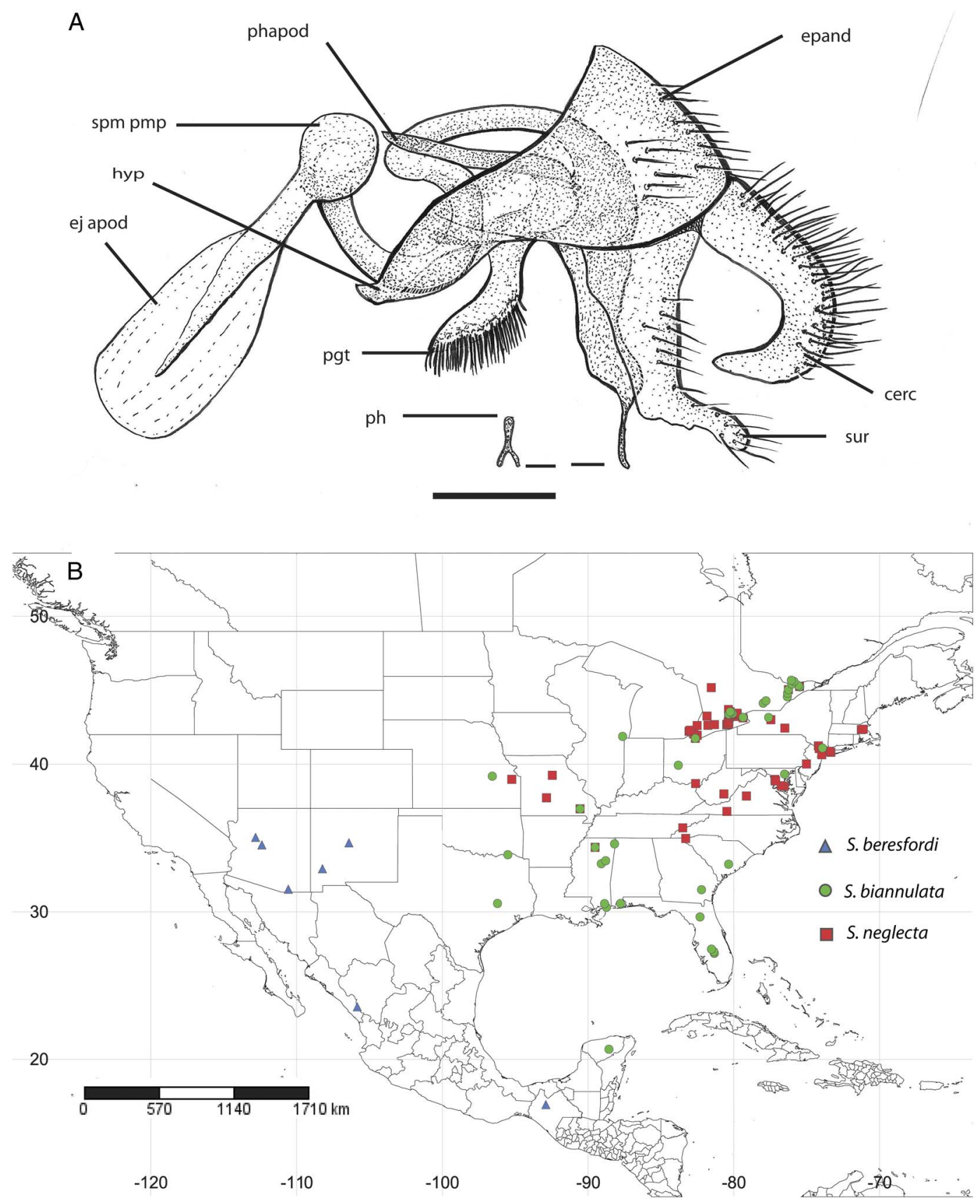

Stylomyia confusa Westwood, 1851: 269. Type locality: Unknown. Type depository: BMNH. Synonymy by Loew 1851: 133.
Stylogaster biannulata: Williston 1883: 93 (redescription and discussion of $S$. stylatus misidentification by Macquart); Williston 1885: 394 
(Conopidae redescriptions); Williston 1893: 120 (discussion of $S$. stylatus misidentification by Roeder); Snow 1903: 216 (checklist of the Diptera of Kansas, United States of America); Tucker 1907: 99 (checklist of insects of Kansas and Colorado, United States of America); Johnson 1910: 772 (checklist of the insects of New Jersey, United States of America); Johnson 1913: 69 (insects of Florida, United States of America); Britton 1920: 189 (checklist of insects of Connecticut, United States of America); Johnson 1925: 180 (checklist of Fauna of New England, United States of America); Leonard 1928: 803 (checklist of the insects of New York, United States of America); Aldrich 1930: 7, 10 (key to New World Stylogaster species; redescription of S. biannulata); Curran 1942: 64 (key to New World Stylogaster species); Camras 1965: 632 (Nearctic catalogue); Camras 1967: 9 (notes, including documentation of 60 specimens over a swarm raid of Eciton burchelli (Westwood) (Hymenoptera: Formicidae) in Mexico); Papavero 1971: 13 (Neotropical catalogue); Camras and Parrillo 1985: 111, 115 (key to New World species; notes); Kotrba 1997: 620 (egg position); Woodley and Judd 1998: 658 (discovery of host, Gryllus rubens Scudder; description of egg and puparium); Gibson et al. 2013: 200, 204 (illustrations of male and female genitalia; phylogeny).

Type material examined: see Remarks section. Material examined: Canada: Ontario: Essex County, Pelee Island, Porchuk property, $41.75^{\circ} \mathrm{N}$, 82.64167 ${ }^{\circ} \mathrm{W}, 28 . v i i i-10.1 x .2002,1{ }^{\top}$, Porchuk and Marshall, Malaise trap, debu216600 (DEBU); Vineland, $43.17080^{\circ} \mathrm{N}, 79.36400^{\circ} \mathrm{W}$, 3.ix.1944, 19, H.R. Boyce, debu115709, (DEBU); Waterloo Region, Blair, Cruickston Creek, $43.37778^{\circ} \mathrm{N}$, 80.34945 ${ }^{\circ} \mathrm{W}$, 3027.ix.2006, 2^⿱乛龰, Marshall and Cheung, debu278338, 278347 (DEBU); The Dells, $43.38194^{\circ} \mathrm{N}, \quad 80.34223^{\circ} \mathrm{W}$, elevation 265 m, 20.vi.2006, 17.vii.2006, 10, Bergeron and Cheung, Malaise trap, debu26874, (DEBU); Puslinch, $43.43334^{\circ} \mathrm{N}, 80.08334^{\circ} \mathrm{W}, 18-20$. ix.1983, 19, Coote and Marshall, Malaise trap, debu1157050 (DEBU); Arkell, $43.53729^{\circ} \mathrm{N}$, 80.16782 ${ }^{\circ} \mathrm{W}, 21 . v i .1986,1{ }^{\star}, 29 . v i .1986,3{ }^{\star}, 2$, E. Lippert, debu1157064, 1157070-4 (DEBU); 18.viii.1987, 1o, 25.viii.1987, 10, 1ㅇ, 30.

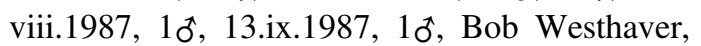

Malaise trap, debu1157065-9 (DEBU); Guelph, $43.54480^{\circ} \mathrm{N}, 80.24816^{\circ} \mathrm{W}, 23 . v i i i .1987,10^{\top}$, Bob Westhaver, debu1157090 (DEBU). Northumberland County, Barr property, $7 \mathrm{~km}$ NE Centreton, $44.13^{\circ} \mathrm{N}, \quad 77.98416^{\circ} \mathrm{W}, 27 . v i .-2 . v i i .2011,1$, 12-26.vii.2011, 19, Brunke and Paiero, Malaise trap, debu1152347, 1154032 (DEBU); Ferris Provincial Park, Drumlin Trail, 44.29134 N, $77.79383^{\circ} \mathrm{W}, 1-15.1 x .2003,1$ \%, P.D. Careless, debu1157092 (DEBU). Chaffey's Locks, Leeds County, $44.5658^{\circ} \mathrm{N}, 76.3242^{\circ} \mathrm{W}$, 31.viii.1973, 19, P. Ward, CNC Diptera 199681 (CNC); North Burgess Township, Lanark County, $44.80696^{\circ} \mathrm{N}$, 76.31263ํ․ 7.ix.1970, 19, 19-26.vii.1971, $1{ }^{\star}$, D.M. Wood, Malaise trap, CNCD199695, 199708 (CNC); Innisville, $45.05140^{\circ} \mathrm{N}$, 76.25050 ${ }^{\circ} \mathrm{W}, 12 . v i i .1961,19$, W.R.M. Mason, CNCD199687 (CNC); Metcalfe, $45.23582^{\circ} \mathrm{N}$, $75.47271^{\circ} \mathrm{W}, 25.1 x .1982$, one abdomen missing, 30.ix.1982, 1, 8.ix.1983, 10, 2ㅇ, 22.ix.1983,

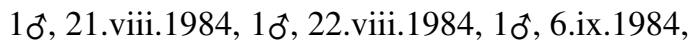
20ิ, 27.vi.1985, 2ㅇ, 28.vi.1985, 1우 5.vii.1985, 1, 7.vii.1986, 20, 5, 17.vii.1986, 1, 11. ix.1993, 19, 12.vii.1993, 1ㅇ, 1ㅇ, 27.viii.1994, 10, B.E. Cooper, CNCD28428, 89252, 195995 , 199713, 199702-7, 199712-6, 199721-3, 199732-5, 199793, 199797, 199805 (CNC); 2 miles North of Metcalfe, $45.26540^{\circ} \mathrm{N}$, 75.48873 ${ }^{\circ} \mathrm{W}, 20 . i v .1952,1$, $, 25 . v i .1982,19,28$. vi.1982, 10ิ 1 , 9 , 11.ix.1982, 10, 1ㅇ, 14.ix.1982, 1ठ, 20.ix.1982, 1ठ, 21.ix.1982, 1ð, 1ㅇ, 22.

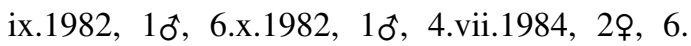
vii.1984, 1, B.E. Cooper, CNCD79762-3, 89251, 199696-7, 199699-701, 199711, 199725-9, 199733 (CNC); Ottawa, near Uplands Airport, $45.33334^{\circ} \mathrm{N}, 75.58334^{\circ} \mathrm{W}, 16$-viii. 1937 , 10, 6우 15.viii.1987, 10, 1ㅇ, 6-12.vii.1989, 1우, J.M. Cumming, Malaise trap, CNCD199698, 199792, 199787-94, 199816-7 (CNC); Dunrobin, $45.42221^{\circ} \mathrm{N}, 76.02026^{\circ} \mathrm{W}, 18 . v i i .1972,3$, H.J. Teskey, Malaise trap, CNCD199685, 199689, 199719, (CNC); Quebec, 4 miles North of Eardley, $45.60581^{\circ} \mathrm{N}, \quad 75.87640^{\circ} \mathrm{W}, 25$. viii.1971, 19, D.M. Wood, CNCD199686 (CNC); Masham Township, Gatineau County, $45.68334^{\circ} \mathrm{N}, \quad 76.05^{\circ} \mathrm{W}, \quad 6-8 . v i i .1974$, one missing abdomen, 2.viii.1974, 1, 7-14.ix.1974, 1ㅇ, 2.viii.1974, 1ㅇ, 6-8.vii.1974, 1, 10-20. vii.1974, 1o, 20-23.viii.1975, 1\%, 25-28. viii.1975, 19, D.M. Wood, CNCD199683, 199691, 199693, 199709, 199717-8, 199720 (CNC). 
Fig. 7. Marjority rule consensus Bayesian-analysis cladogram based on COI sequence data. Numbers at nodes indicate posterior probability support measures. Dalmannia, Myopa, Physoconops, and Zodion were defined as the outgroup.

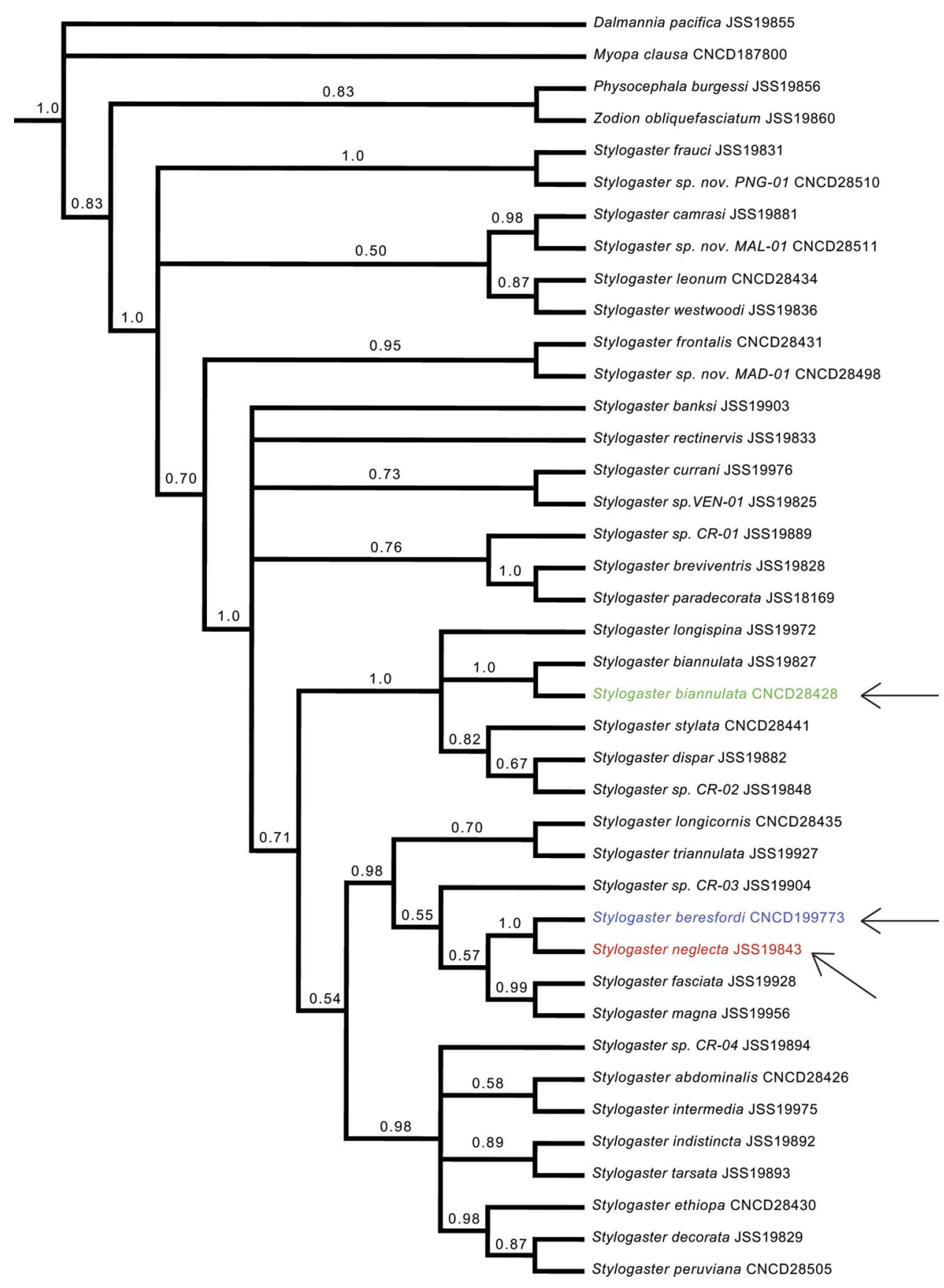

Mexico: Yucatan: Chichen Itza, $20.68428^{\circ} \mathrm{N}$, $88.56778^{\circ} \mathrm{W}, \quad$ no/day.vi.1929, $1524 \mathrm{~m}, \quad 2 \%$, JSS26053, 26056 (AMNH). United States of
America: Alabama: Baldwin County, Bon Secur, $30.3^{\circ} \mathrm{N}, 88.74^{\circ} \mathrm{W}, 19 . x .2004,5$ ㅇ, E. Benton, Malaise trap, CNCD199736, 199738-41 (CNC); 
Fig. 8. Neighbour-joining tree based on COI sequence data.

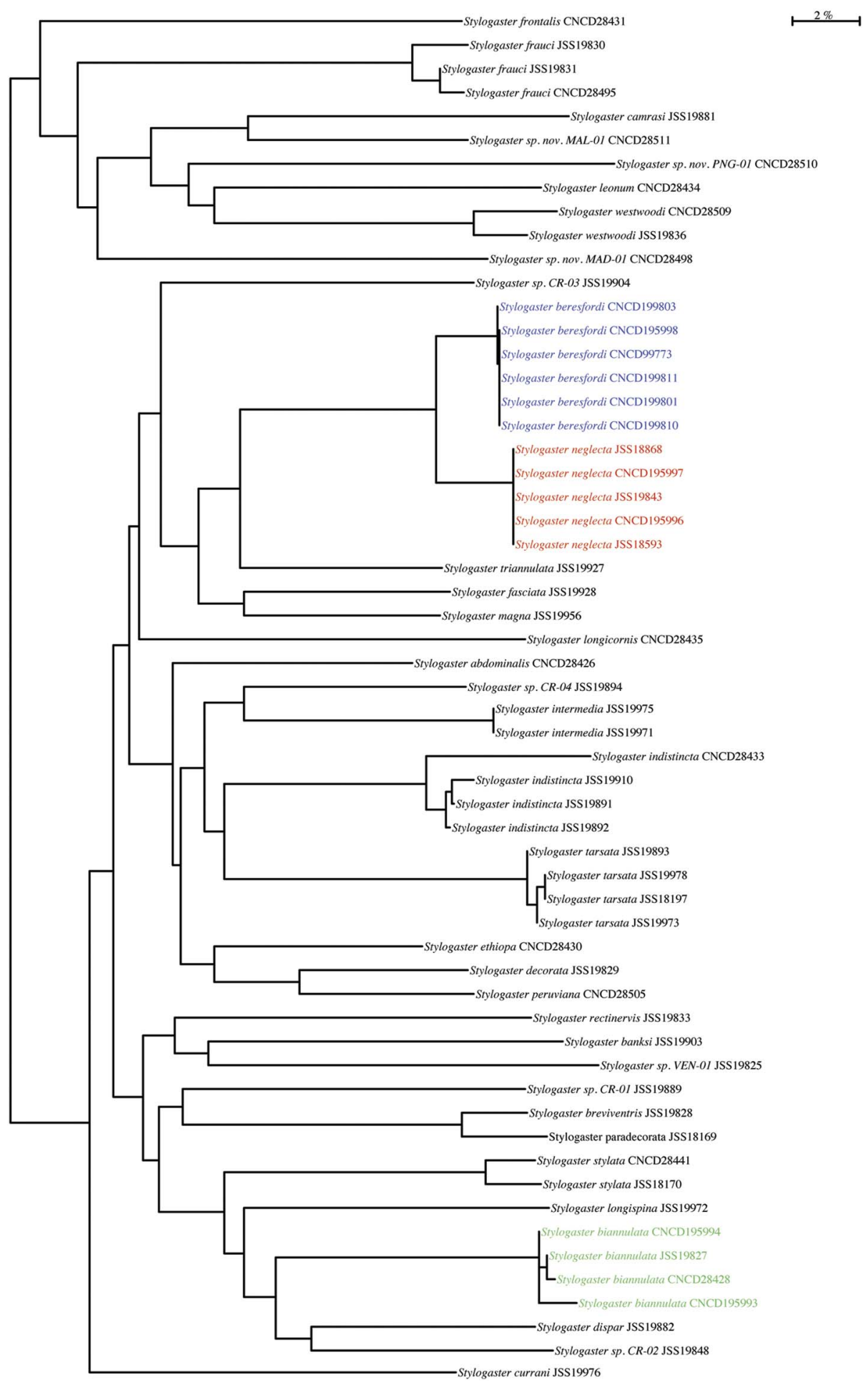


Auburn University, $30.55^{\circ} \mathrm{N}, 88.87^{\circ} \mathrm{W}, 15 . x i i .2004$, 29, E. Benton, Malaise trap, CNCD195993, 199819 (CNC); Silver Hill, $30.56^{\circ} \mathrm{N}, 87.77^{\circ} \mathrm{W}$, 15.xii.2004, $1{ }^{\star}$, E. Benton, Malaise trap, CNCD195994 (CNC). Florida: Okeechobee County, Archbold Biological Station, Lake Placid, Highlands County, Trail 1 SSo, $27.188^{\circ} \mathrm{N}, 81.338^{\circ} \mathrm{W}, 9$.

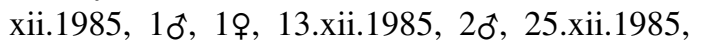
$3{ }^{\star}, 1$, 9 M. Deyrup, Malaise trap, debu1157055, 1157056-62, DEBU; Okeechobee County, Archbold Biological Station, Lake Placid, Highlands County, Trail 1 SSo, $27.18966^{\circ} \mathrm{N}$, 81.33813ํW, 15.xii.1985, 10, 18.xii.1985, $10^{\star}$, 1ㅇ, S.A. Marshall, 14-17.iv.1989, 50^, Malaise trap, debu1157041-3, 1157045-9 (DEBU); Okeechobee County, Archbold Biological Station, Lake Placid, Highlands County, Trail 1 SSo, $27.20736^{\circ} \mathrm{N}, 81.33813^{\circ} \mathrm{W}, 4-10 . v i i i .1987$, 10َ, 1ㅇ, CNCD199800, 199814 (CNC); Okeechobee County, Archbold Biological Station, Lake Placid, Highlands County, Trail 1 SSo, $27.297^{\circ} \mathrm{N}, 81.37^{\circ} \mathrm{W}, 9 . x i i .1985,80^{\circ}, 2$ ㅇ, 20. xii.1985, 3ð, 3ㅇ, 9.xii.1985, 10, 1ㅇ, M. Deyrup, Malaise trap, debu1157052-4, 1157063, 1157075-89 (DEBU); Highlands County, Hammock State Park, $27.46667^{\circ} \mathrm{N}, 81.53334^{\circ} \mathrm{W}$, 17.iv.1989, 1오 B.J. Sinclair, 13-17.iv.1989, 1우, J.E. Swann, Malaise trap, CNCD199710, debu1157051 (CNC, DEBU); Gainesville, $29.65^{\circ} \mathrm{N}$, $82.31667^{\circ} \mathrm{W}, 24 . i v .1952,10^{\star}$, G.S. Walley, 8-22.xii.1986, 19, W. Mason, Malaise trap, CNCD195559, 199795 (CNC). Georgia: Pierce County, $5 \mathrm{~km}$ North of Bristol, $31.4935^{\circ} \mathrm{N}$, $82.21492^{\circ} \mathrm{W}, 18.1 \mathrm{v} .1989,1{ }^{\star}$, K.N. Barber, sweep, roadside, debu1157044, (DEBU). Illinois: Chicago, $41.87811^{\circ} \mathrm{N}, 87.6298^{\circ} \mathrm{W}, 6 . v i i .1895$, 19, W.M. Wheeler collection, JSS26058 (AMNH). Kansas: Manhattan, $39.18361^{\circ} \mathrm{N}$, 96.57167 ${ }^{\circ}$ W, 29.x.1932, 19, C.W. Sabrosky, JSS26055 (AMNH). Mississippi: Winston County, Tombigbee National Forest, $33.255^{\circ} \mathrm{N}$, 89.091389 W, 10.viii.1952, 19, J.M. Cumming, Malaise trap, CNCD222738 (CNC); Agricultural College, $33.45553^{\circ} \mathrm{N}, 88.79042^{\circ} \mathrm{W}, 8 . x .1920,1$, 6.x.1921, 1ㅇ, CNCD199679, 199684 (CNC); Oxford, $34.36649^{\circ} \mathrm{N}, 89.51924^{\circ} \mathrm{W}$, v.1940, 30ิ 1\%, 10.vi.1945, 1, F.M. Hull, Frank M. Hull Collection C.N.C. 1973, CNCD79761, 85163,199682, 199688, 199692 (CNC); Tishomingo State Park, $34.59941^{\circ} \mathrm{N}, 88.18456^{\circ} \mathrm{W}, 20$. v.2013, G.A. Dahlem, Malaise trap, JSS26307,
CNC; Rosedale, $39.32010^{\circ} \mathrm{N}, 76.51551^{\circ} \mathrm{W}, 9$. ix.1922, 1ㅇ, 14.ix.1922, CNCD199678, 199680 (abdomen and head missing) (CNC); Williamsville, $36.97249^{\circ} \mathrm{N}, 90.54833^{\circ} \mathrm{W}, \mathrm{x}-\mathrm{xi} .1968,2{ }^{\star}$, Malaise trap, 10, 19, J.T. Becker, CNCD199690, 199694, 199730-1 (CNC). New York: Rochester, $43.16103^{\circ} \mathrm{N}, 77.61092^{\circ} \mathrm{W}, 18 . i x .1933,19$, R.L. Post, JSS26054, AMNH; Nyack, $41.09065^{\circ} \mathrm{N}$, $73.91792^{\circ} \mathrm{W}, 1883,1$,, JSS26057 (AMNH). Ohio: Springfield, $39.92423^{\circ} \mathrm{N}, 83.80882^{\circ} \mathrm{W}, 8$. ix.1937, 1\%, R.H. Crandall, JSS26059 (AMNH); South Carolina: Dorchester County, Francis Beidler Forest, $10 \mathrm{~km}$ Northeast of Harleyville, $33.22064^{\circ} \mathrm{N}, \quad 80.35419^{\circ} \mathrm{W}, \quad 28 . i v .1987, \quad 10^{\circ}$, Malaise trap, CNCD199813 (CNC); Texas: Hardin County, 4 miles East of Silsbee on Route 418, Roy E. Larson Sandylands Sanctuary, $30.3^{\circ} \mathrm{N}, \quad 88.74^{\circ} \mathrm{W}, \quad 17-19 . v .1993,19, \quad$ J.M. Cumming, Yellow Pan Trap and Malaise Trap, CNCD199737 (CNC); Brazos County, College Station, Lick Creek Pk., $30.56223^{\circ} \mathrm{N}$, 96.21472 ${ }^{\circ} \mathrm{W}$, 30.iii-5.iv.2000, 1ㅇ, 5-9.iv.2000, 1\%, M. Buck, Malaise trap, debu110561, 114275, DEBU; Lamar County, Camp Maxey, $33.86427^{\circ} \mathrm{N}$, 95.5066 ${ }^{\circ} \mathrm{W}, 21 . x-8 . x i i .2003,19$, W. Godwin, Malaise trap, JSS19827 (CNC).

Diagnosis: Antennae with near equal lengths of pedicel and flagellum (Fig. 3A); ovipositor of female stout compared to $S$. neglecta and $S$. beresfordi (S. biannulata stylus Fig. 3E).

Redescription: Male: Body length 6-8 mm. Head: Face pale yellow with extremely faint silver microtomentum extending narrowly between eyes and frontal vitta with four to six variably pale yellow or black setae in a row along inside each eye; facial carina sharp and narrow; ocellar triangle with slight, irregularly rounded ocellar protrusion with two setae just behind protrusion; frontal vitta and triangle are somewhat dull pale yellow near scape and becomes dark brown to black just before ocellar protrusion, entirely surrounded by a dull and darker V-shaped area (Fig. 3A); back of the head just behind eyes with distinctive patches of silver microtomentum, and long white setulae on lateral occiput; scape, pedicel and flagellum mainly yellow with darker brown on the flagellum, with feather-like arista mainly yellow, and pedicel mainly darker brown; flagellum equal in length with pedicel; scape with short subtle and sparse black pile; pedicel with moderately long, spikey black pile. 
Thorax: Laterally pale yellow with light brown maculation on anepisternum and katepisternum (Fig. 3F); thorax dorsally longer than wide (Figs. 3B, G); dorsal anterior postpronutum paler with pale microtomentum and without long setae, dorsal thorax mainly black with slightly lighter brown area posteriorly; dorsal thorax covered with short pale setulae; four long black setae fairly evenly spaced along each side of the dorsal lateral edge of thorax distally, with two postallar callus setae closer together; scutellum dark brown to black with two posterior long black setae; scutellum slightly lighter than rest of dorsal surface of thorax.

Legs: Coxae pale yellow with hind coxa slightly darker; fore coxa with several long pale and black setae; hind coxa with mainly black, long and short setae, mid coxa with several long pale and sparse black setulae anteriorly; hind legs mainly covered in short black setulae except ventral surface of fore femur with longer black setulae; fore and mid legs covered in pale setulae with only a few darker setulae becoming more regularly dark after tarsomere 3; hind femur pale yellow with two darker brown bands (Figs. 3F, G); fore and mid tibiae and tarsi pale yellow setulae; while hind tibia is mostly pale, becoming more stout and broad, and abruptly darker brown basally, colour extends throughout hind tarsi (Fig. 3F); hind tibia has three fairly reduced and subtle basal spurs; fore and mid tibiae with single pale spur; tarsomere 2 about $3 / 4$ length of tarsomere 1 ; tarsomere 3 is about $1 / 3$ length of tarsomere 2; tarsomere 3-5 equal to each other; fore and mid tarsi pale yellow, except for brown 5th.

Wing: Costal vein covered in short setulae with one long black seta dorsal-basally.

Abdomen: More bulbous distally; tergites mainly pale yellow with gradient darker brown banding, darker towards posterior margin of tergite, when viewed dorsally (Fig. 3G); ventral sternites mainly absent except sternite 5 , which bears sharp carina, reduced overall; dorsal abdomen entirely covered in short black setulae, anteroventrally tuft of paler yellow setae present; viewed dorsally, tergite 3 appears somewhat fluted posteriorly, tergite 4 bulbous.

Terminalia: Epandrium not bulbous, rather flattened dorsally, without long, posterior bristles, with many fine black setulae; surstylus slightly
L-shaped with slight second lobe at bend, distal lobe with sparse black setulae on outer face and shorter black setae on inner face (Fig. 5B); cercus single-lobed, and sickle-shaped, sharp and pointed distally; dorsally, cercus with many thin, long black setae; postgonite somewhat elongate, carnate dorsally, with short, sharp black spine-like setae ventrally only, appearing brush-like; phallus Y-shaped, single stranded later dividing into short double-stranded form, dark brown (Fig. 5B); phallapodeme cylindrical and elongate, becoming narrower distally; sperm pump only slight, much smaller than epandrium (about size of surstylus), rounded; ejaculatory apodeme is thin, somewhat narrow, leaf or arrow-shaped, thin and somewhat flat (Fig. 5B).

Female: Similar to male, except for genitalia; ovipositor shorter and stouter than in S. neglecta and $S$. beresfordi, with a slightly uneven lateral groove (Fig. 3E).

Genitalia: Tergite 7 or ovipositor, cylindrical, only somewhat elongate and pale with sparse, short setae, and a lateral groove, or crease (Fig. 3E); tergite 8 cylindrical and $1 / 3$ as long as ovipositor with longer, coarser setae; tergite 9 short and fused dorsally, somewhat protruding dorsally, lateral lobes of sternite 8 with sparse setulae (Fig. 3D); hypoproct appears mildly arrow-shaped, short and stout, only moderately pointed with many medium length setae; cercus slightly elongate and sickleshaped, with long black spines, not extending to tip of hypoproct (Fig. 3D).

Egg: The eggs of $S$. biannulata have been thoroughly described by Woodley and Judd (1998) but are re-illustrated and described here for comparative purposes (Fig. 3C). Anterior tip (nonmicropylar end) sharply pointed and highly sclerotised with pair of ventral, posterior-facing (downward) spines or barbs, slightly longer than $S$. beresfordi or $S$. neglecta (S. beresfordi and $S$. neglecta eggs, Figs. 2D, 4C); barbs are often encased within thin, translucent film; tip in shaped of arrowhead or harpoon when viewed ventrally or dorsally; body elongate, cylindrical, becoming gradually more bulbous towards the posterior (micropyle end), club shaped; longitudinal slit opening between two sclerotised barbs where the eversible sac originates upon inflation; viewed laterally, anterior end appears much like a sharp and pointed blade while egg body posteriorly clavate; under high magnification surface appears 
sculptured, scale-like, that are less defined or altogether absent towards the posterior.

Hosts: Woodley and Judd (1998) noted that Gryllus rubens Scudder serves as the host for $S$. biannulata. These crickets were often parasitised more than once with larvae emerging roughly 19-25 days later. Camras (1967) documented a collection of 60 adult specimens taken over a swarm raid of Eciton burchelli in Mexico. It thus seems likely that they also attack more than just Gryllus rubens. More work is needed to understand host use in species of Stylogaster.

Known distribution: Stylogaster biannulata occurs from southern Mexico north to Oklahoma, Kansas and Nebraska, east to Florida in the United States of America and north to Ontario and southern Québec, Canada (Fig. 6B).

Comments: Four COI sequences have been obtained and are published in GenBank (Table 1). Intraspecific variation amounted to $0.2-1.5 \%$. The uncorrected pairwise genetic distance between $S$. biannulata and S. beresfordi is $15.0-21.9 \%$ and between $S$. biannulata and $S$. neglecta is $17.9-19.9 \%$. Based on a combined five-gene and morphology phylogenetic analysis of Conopidae, S. biannulata was hypothesised to be in a different species group than $S$. neglecta (Gibson et al. 2013). Eleven of the 59 conopid species included in their data set were Stylogaster. We now have additional COI data available for conopids and include 35 species of Stylogaster in the Bayesian analysis presented here (Fig. 7). We recover a similar pattern of relationships to those found by Gibson et al. (2013) despite using only COI data in the analysis.

The holotype of $S$. biannulata is missing and has been missing for decades. It was deposited in the Academy of Natural Sciences in Philadelphia. Until the authors have a chance to visit this collection in person it is likely not wise to nominate a neotype. Given the distinctiveness of the taxon, it also seems unnecessary to designate a neotype.

\section{Stylogaster neglecta Williston}

(Figs. 4A-F, 6)

Stylogaster neglecta Williston, 1883: 91. Type locality: United States of America, Connecticut. Type depository: syntypes MCZ, UKAL.

Stylogaster neglecta Williston. Williston 1894: V4 (checklist of insects); Townsend 1895: 64 (checklist of Diptera of North America); Johnson 1925: 180 (catalogue of insects of New England, United States of America); Snow 1903: 216 (checklist of Diptera for Kansas, United States of America); Jones 1907: 251 (a preliminary checklist of conopids in Nebraska, United States of America); Williston 1908: 262 (description and checklist); Banks 1912: 109 (checklist of insects); Banks 1916: 200 (checklist of insects of northern Virginia, United States of America); Greene 1913: 45 (checklist and notes on natural history and behaviour); Kröber 1914: 349 (catalogue of insects); Britton 1920: 189 (checklist of insects of Connecticut, United States of America); Johannsen 1928: 803 (checklist of insects of New York, United States of America); Aldrich 1930: 7, 10 (key to New World Stylogaster species; redescription of $S$. neglecta); Curran 1942: 64 (key to New World Stylogaster species); Papavero 1971: 13 (Neotropical catalogue); Camras and Parrillo 1985: 111, 115 (key to New World species; notes); Kotrba 1997: 620 (egg position); Gibson et al. 2013: 200, 204 (illustrations of male and female genitalia; phylogeny).

Type Material Examined: Holotype ot, [United States of America: Connecticut], Osten Sacken Coll., Type Wlstn., MCZ-ENT00000450 (MCZ). Other material examined: Canada:

Ontario: Essex County, Pelee Island, Porchuk property, $41.75^{\circ} \mathrm{N}, 82.64167^{\circ} \mathrm{W}, 26 . v i .-8 . v i i .2002$,

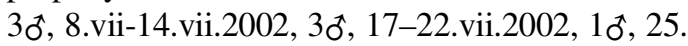
vii.2002, 10, 1o, 25.vii-3.viii.2002, 20, 2o, B. Porchuk, Malaise trap, debu198135, 198141, 198144, 198158-60, 216482, 216484, 216486-7, 227820-2 (DEBU); Essex County, Point Pelee National Park, $41.95834^{\circ} \mathrm{N}, 82.5125^{\circ} \mathrm{W}, 19$. vii.1983, 1\%, Marshall, Logan and Grigsby, 20. vii.1978, 15ð, 2o, J.M. Cumming, 16.vii.1962,

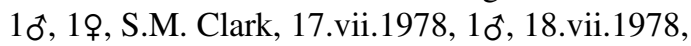
10, 31.vii.1978, 10, D. Morris, 18.vii1978, 2ð, W.A. Attwater, 20.vii.1978, 10ð, 22.vii.1979, 10َ, K.N. Barber, debu19035, CNCD199758-9, debu6005-18, 6023-8, 6030, 6032-6, 19032-3, 19036-7 (CNC, DEBU); Kingsville, 42.03650 ${ }^{\circ}$, $82.73909^{\circ} \mathrm{W}, 8 . v i i .1977,40^{\star}, 1$ \%, W.A. Attwater, debu1157113-5, 1157117, 1157119 (DEBU); Windsor, $\sim 1.5 \mathrm{~km} \mathrm{~S}$ Ojibway Prairie, $42.22611^{\circ} \mathrm{N}$, 83.07416 ${ }^{\circ} \mathrm{W}, \quad 19-30 . v i .2001,2 \widehat{0}, 30 . v i-17$. 
vii.2001, 1, P. Pratt, 18-31.vii.2001, 10, 2ᄋ, S.M. Paiero, $42.29267^{\circ} \mathrm{N}, \quad 82.99333^{\circ} \mathrm{W}, 4$. vii.1984, 20ิ, M.T. Kasserra, Malaise trap, debu1106076-7, 1107993-4, 1108002, 1108109, 1157094, 1157104 (DEBU); Maidstone Conservation Area, $42.21383^{\circ} \mathrm{N}, 82.78694^{\circ} \mathrm{W}, 21 . v i i .2000$, $10^{\star}, 1$,, S.A. Marshall, debu137396 (DEBU); Walpole, $42.61504^{\circ} \mathrm{N}, 82.51457^{\circ} \mathrm{W}, 12 . v i i .1979$, 19, D. Morris, debu1157098 (DEBU); Elgin County, Fingal Wildlife Management Area, $42.67948^{\circ} \mathrm{N}, 81.32660^{\circ} \mathrm{W}, 13 . v i i i .1997,1$, 29. vi.1998, 1ð, 3.viii.2000, 1ㅇ, 27.vii.2002, 10, 1ㅇ, Ian Carmichael, Newport Forest, $\sim 3 \mathrm{~km} \mathrm{SW}$ of Wardsville, $\quad 42.63111^{\circ} \mathrm{N}, \quad 81.77861^{\circ} \mathrm{W}, \quad 30$. vii.2009, 10, G.F.G. Miranda, debu318212, CNCD195996-9, 199818 (CNC, DEBU); Regional Municipality of Haldimand-Norfolk, Cronmiller property, $\sim 6 \mathrm{~km} \mathrm{~W}$ St. Williams, $42.6725^{\circ} \mathrm{N}, 80.49056^{\circ} \mathrm{W}, 20 . v i i .2011,1{ }^{\star}$, S.M. Paiero, debu1148553, DEBU; Manestar Tract, $6 \mathrm{~km}$ NNW St. Williams, $42.70472^{\circ} \mathrm{N}$, $80.46056^{\circ} \mathrm{W}, 3 . v i i i .2001,19$, M. Parchami-Araghi, debu166472 (DEBU); Turkey Point Provincial Park, $42.71167^{\circ} \mathrm{N}, 80.34223^{\circ} \mathrm{W}, 6-22 . v i i .2009$, 19, 22.vii-3.viii.2009, 10, 3ㅇ, S.M. Paiero, Malaise trap, debu336037, 1150079, 1150081, 1150085 (DEBU); Delhi Simcoe Railway, $42.85^{\circ} \mathrm{N}$, $80.38334^{\circ} \mathrm{W}, 14 . v i i .2001,20^{\star}$, 19, S.M. Paiero, sweep, debu1104992, 1106599, 1116587 (DEBU); Jordan, $43.13334^{\circ} \mathrm{N}, 79.36667^{\circ} \mathrm{W}, 13 . v i i .1919$, H. Curran, Compared with type (of Stylogaster neglecta Williston, 1883); missing abdomen, 4. vii.1920, 1ðَ, C.H. Curran, 13.vii.1919, 1, 14.

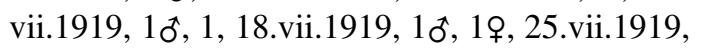
10َ, W.A. Ross, CNCD199770, 199778-9, 199781-3, 199785, CNC, 17.vii.1919, 10, W.A. Ross, debu1157108 (DEBU); Brant County, Brantford Railway Prairie, $43.16667^{\circ} \mathrm{N}$, $80.31667^{\circ} \mathrm{W}$, 24.vii.2002, 19, S.M. Paiero, debu1115762 (DEBU); Hamilton, $43.23333^{\circ} \mathrm{N}$, 79.95 ${ }^{\circ} \mathrm{W}, \quad 24 . v i i .1982,10^{\star}$, Kevin Barber, debu1157099 (DEBU); Pinery Park, Chalet, $43.255124^{\circ} \mathrm{N}, 81.8388297^{\circ} \mathrm{W}$, 9.vii.1991, $10^{\dagger}$, J. Malaise trap, debu1157106 (DEBU); Dundas, $43.263453^{\circ} \mathrm{N}, 79.9527^{\circ} \mathrm{W}, 7-11 . v i i .1970,10^{\top}$, 7-11.vii.1972, 40ิ, 29, D.M. Wood, CNCD 28437 (CNC); 24.vii.1975, 1ðَ, D.J. McComb, 21.vii.1981, 3ðَ, Cyrus Farivar, debu1157100, 1157102, 1157118, 1157112 (DEBU); Waterloo Region, Blair, RARE, Cruickston Creek, $43.37778^{\circ} \mathrm{N}, \quad 80.34945^{\circ} \mathrm{W}, \quad 301, \quad 27.1 x .2006$,
10, Marshall and Cheung, debu278326 (DEBU); Cambridge, $\quad 43.38334^{\circ} \mathrm{N}, \quad 80.31667^{\circ} \mathrm{W}, 24$. viii.1989, 1\%, M.K. Sears, Malaise trap, debu1157097, DEBU; Freelton, 43.39779 N, $80.03642^{\circ} \mathrm{W}$, 19.viii.1984, 10, M.T. Kasserra, debu1157105 (DEBU); Regional Municipality of Halton, Oakville, nr. Hwy 25 and Burnhamthorpe Rd., $\quad 43.45389^{\circ} \mathrm{N}, \quad 79.79223^{\circ} \mathrm{W}, \quad 26 . v i i-16$. viii.2006, 60, 5ㅇ, S.M. Paiero, Malaise trap, debu285658-63, 285665-7, 285686-7 (DEBU); Bronte Creek Provincial Park, $43.415^{\circ} \mathrm{N}$, 79.76667 ${ }^{\circ} \mathrm{W}$, 19.vii.2002, 50ิ, K.N. Barber, sweep, debu1157109-11, 1157120-1 (DEBU); Guelph, 43.54480 $\mathrm{N}, 80.24816^{\circ} \mathrm{W}$, 27.vi.1955, 10, D.H. Pengelly, debu 1157116 (DEBU); Fergus, $43.7^{\circ} \mathrm{N}, 80.36667^{\circ} \mathrm{W}$, 4.vii.1990, 19, S.A. Marshall, Malaise trap, debu1157095 (DEBU); Bothwell, $45.05140^{\circ} \mathrm{N}, 76.25050^{\circ} \mathrm{W}$, 18.vii.1962, 1, S.M. Clark, missing abdomen, CNCD199784 (CNC); 2 miles North of Metcalfe, $45.26540^{\circ} \mathrm{N}, 75.48873^{\circ} \mathrm{W}, 16 . v i i .1982$, 19, B.E. Cooper, CNCD199775 (CNC). United States of America: Georgia: Rabun Bald, Rabun County, 34.964827 ${ }^{\circ} \mathrm{N}, 83.298647^{\circ} \mathrm{W}, 914,14 . v i i .1957$, 10ิ J. J.G. Chillcott, CNCD199755 (CNC). Kansas: Lawrence, $38.97166^{\circ} \mathrm{N}, 95.23525^{\circ} \mathrm{W}$, 22.vi.1922, 10, C.H. Curran, CNCD199780 (CNC). Kentucky: Manifee county, near Frenchburg, $37.98^{\circ} \mathrm{N}, 80.68^{\circ} \mathrm{W}, 2-8 . v i i .1997$, 10َ, 15-22.vii.1997, 10, 2ᄋ, Abnee and Sharkey, MT, Malaise Trap, LACM ENT 319801, 319802, 319803, 319804 (LACM). Maryland: Calvert County, Port Republic, $38.5^{\circ} \mathrm{N}, 76.53334^{\circ} \mathrm{W}$,

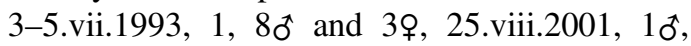
D.M. Wood, 7-8.viii.1993, 1क, Xuekui Sun, CNCD79785, 89262-3, 199762-7, 199769, 199806, debu1157101 (CNC, DEBU); Patuxent Wildlife Center, $38.53996^{\circ} \mathrm{N}, \quad 76.74768^{\circ} \mathrm{W}$, 6-22.viii.1979, 1o , 2o, 5.viii.1979, 1\%, E.E. Grissell and M. Schauff, CNCD199807-9, 199815 (CNC); Plummers Island, $38.97004^{\circ} \mathrm{N}$, $77.17880^{\circ} \mathrm{W}$, 3.vii. 1921 , one sex not determined, 14.vii.1921, 50, one sex not determined, J. Bequaert collection, JSS23095, 23096, 23097, 23098, 23099, 23100, 23101 (MCZC); 18. vii.1909, 1\%, G.P. Engelhardt, JSS23102 (MCZC). Massachusetts: Auburndale, $42.34334^{\circ} \mathrm{N}$, 71.24771 ${ }^{\circ} \mathrm{W}, \quad$ 16.vii.1903, 10\%, CNCD199756 (CNC); Riverside, $42.36768^{\circ} \mathrm{N}, 71.11367^{\circ} \mathrm{W}, 12$. vi.no/year, 10َ, 12.vi.1903, one sex not determined, A.P. Morse, JSS23103, 23104 (MCZC). 
Mississippi: Oxford, $34.36649^{\circ} \mathrm{N}, 89.51924^{\circ} \mathrm{W}$, v.1940, 6ð̊, F.M. Hull, Frank M. Hull Collection C.N.C. 1973, CNCD199751-2, 199760, 199771, 199776-7 (CNC). Missouri: Williamsville, 36.97249 ${ }^{\circ} \mathrm{N}, 90.54833^{\circ} \mathrm{W}, 14 . v i i .1969,10^{\uparrow}, 22$. vii.1969, 1\%, Malaise trap, CNCD199753, 199757 (CNC); La Clede County, Bennett Springs State Park, $37.72141^{\circ} \mathrm{N}, 92.85296^{\circ} \mathrm{W}$, 1.viii.1984, 10`, B.V. Brown, debu1157103 (DEBU); Rufolf Bennitt Wildlife Area, Randolf County, south of Moberly, $39.24812^{\circ} \mathrm{N}$, 92.45547 ${ }^{\circ} \mathrm{W}, 25 . v i i .1970,10^{\circ}$, R. Heitman, JSS26125, (AMNH). New Jersey, Riverton, $40.01150^{\circ} \mathrm{N}, 75.01489^{\circ} \mathrm{W}, 21 . v i i .1920,1,30^{\star}$, 19, Frank M. Hull Collection C.N.C. 1973, CNCD199743, 199747-50 (CNC); Alpine, $40.95593^{\circ} \mathrm{N}, 73.93124^{\circ} \mathrm{W}, 28 . v i i .1946,30^{\star}, 1$ 우 S.C. Harriot, JSS26085, 26086, 26087, 26088 (AMNH); Kalbfleisch Research Station, Huntington, Long Island, $40.80482^{\circ} \mathrm{N}, 73.33623^{\circ} \mathrm{W}$, 9.vii.1918, 10, A. Nicolay, JSS26113, AMNH; Ramsey, $41.05741^{\circ} \mathrm{N}, 74.14089^{\circ} \mathrm{W}$, 4.viii.1935, $10^{\star}$, JSS26114, AMNH; $40.01150^{\circ} \mathrm{N}, 75.01489^{\circ} \mathrm{W}$, 15.vii.no/year, 1ㅇ, 5.viii.no.yr, 10, 30.vii.1888,

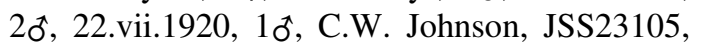
23106, 23107, 23108, 23109, 23110 (MCZC). New York, Kalbfleisch Research Station, Huntington, Long Island, $40.80482^{\circ} \mathrm{N}$, 73.33623ํ․ 26.vii.1962, 19, P.H. Arnaud, Malaise trap, CNCD199786 (CNC); Cold Spring Harbor, Long Island, $40.87148^{\circ} \mathrm{N}, 73.45678^{\circ} \mathrm{W}$,

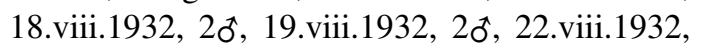

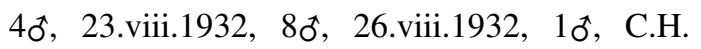
Curran, JSS26060, 26061, 26062, 26063, 26064, 26064, 26065, 26066, 26067, 26068, 26069, 26070, 26071, 26072, 26072, 26073, 26074, 26075, 26076, 26077, 26078, 26079, 26079, 26080, 26081 (AMNH); Tuxedo, Station for the Study of Insects, $41.23766^{\circ} \mathrm{N}, 74.19445^{\circ} \mathrm{W}, 25$. viii.1928, 10, 28.viii.1928, 10, 1ㅇ, C.H. Curran, JSS26082, 26083, 26084, AMNH; 27.viii.1932, 1ð̊, 1ㅇ, Ethel Curran, JSS26073, 26081, AMNH; $40.80482^{\circ} \mathrm{N}, 73.33623^{\circ} \mathrm{W}, 19 . v i i .1962,1 \delta^{\star}, 1$ \% , 24.vii.1962, 4ㅇ, 26.vii.1962, 1ð, 4ㅇ, 28.vii.1962, 4ㅇ, 1.15.viii.1962, 3ㅇ, P.H. Arnaud, JSS26089, 26090, 26091, 26092, 26092, 26093, 26094, 26095, 26096, 26097, 26098, 26099, 26100, 26101, 26102, 26103, 26104, 26106, 26107, 26113, 26114 (AMNH); 19.vii.1962, 10ㅈ, Rozen, Arnaud, Hessel, Woods, Statham, JSS26105, AMNH; 19.24.vii.1976, 10, 19.28.vii.1976, 10َ, 25.31.vii.1976, 2ð, M. Kamran JSS26108, 26109, 26110, 26110 (AMNH); 8.18.viii.1971, $1{ }^{\star}$, P. and B. Wygozinsky, JSS26112, AMNH; Long Island, Flatbush, water works, $40.64092^{\circ} \mathrm{N}$, 73.96243 ${ }^{\circ} \mathrm{W}, 11$.vii.1890, 10 ${ }^{\circ}$ JSS26124 (AMNH); Fishers, $43.0094^{\circ} \mathrm{N}, 77.45514^{\circ} \mathrm{W}$, 9.vii.1933, 3ठ, 16.vii.1933, 40`, JSS26115, 26116, 26117, 26118, 26119, 26120, 26121 (AMNH); Mosholu, $40.87700^{\circ} \mathrm{N}, \quad 73.88489^{\circ} \mathrm{W}, \quad$ (no date) $10^{*}$, JSS26122 (AMNH); Ithaca, Tompkins County, $42.44458^{\circ} \mathrm{N}, 76.49926^{\circ} \mathrm{W}, 22 . v i i .1979,1$, 23. vii.1979, 3ㅊ, 1우, 3.viii.1979, 1초. J.E. Rawling, JSS23116, 23117, 23118, 23119, 23120, 26121 (MCZC). Ohio: Lawrence County, Dean State Forest, $38.68716^{\circ} \mathrm{N}, 82.62133^{\circ} \mathrm{W}$, 13.vii. 1989 , $10^{\top}$, S.A. Marshall, debu1157096 (DEBU). Tennessee: Sevier County, Great Smoky Mountains National Park, ATBI Plot: Twin Creeks, $35.685^{\circ} \mathrm{N}$, 83.499 ${ }^{\circ}$ W, 21.vii-9.viii.1999, 1ð`, Parker, Stocks, Perterson, Malaise trap, CNC Diptera 199761 (CNC). Vermont: Calisol, 18.viii.1802, 10, JSS26123 (AMNH). Virginia: Buffalo Mountain, $2.5 \mathrm{~km} \mathrm{~W}$ of Moles Road, $36.79605^{\circ} \mathrm{N}$, 80.47616 ${ }^{\circ} \mathrm{W}, 1211$, 24.vii.2009, 10, J. Skevington, JSS18593 (CNC); Fish Hatchery Lane, $2.5 \mathrm{~km}$ S Montebello, $37.84191^{\circ} \mathrm{N}, 79.13125^{\circ} \mathrm{W}, 825 \mathrm{~m}$, 22.vii.2009, 4ð, J. Skevington, JSS18799, 18868-9, 19843 (CNC); Falls Church, $38.86667^{\circ} \mathrm{N}$, $77.16667^{\circ} \mathrm{W}, 14 . v i . n o / y e a r, 1 \%$, 22.vi.no/year,

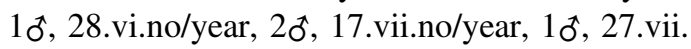
no/year, 10, 5.viii.no/year, 10, N. Banks, JSS23088, 23089, 23090, 23091, 23092, 23093, 23094 (MCZC); Glencarlyn, $38.86379^{\circ} \mathrm{N}$, $77.12694^{\circ} \mathrm{W}$, 17.vi.no/year, $1 \delta^{\dagger}$, 21.vi.no/year, 1\%, 2.vii.no/year, 10, N. Banks collection, JSS23111, 23112, 23113 (MCZC).

Diagnosis: Distinguished from S. biannulata by the subequal flagellum and pedicel; the flagellum is nearly twice as long as the pedicel (Fig. 4A); ocellar triangle usually light in colour (tan or yellow) (Figs. 4A, F), lighter than in $S$. beresfordi; long ventral and lateral setae on first abdominal tergite are usually black rather than pale, though this character is somewhat variable; male surstylus and postgonite are both narrower and more elongate than in S. beresfordi (Fig. 5B).

Redescription: Male: Body length 6-7 mm.

Head: As in S. beresfordi except the following: ocellar triangle shiny and pale yellow, rarely light brown, surrounded by dull and darker $\mathrm{V}$-shaped area (Fig. 4A); flagellum $2 \times$ length of the pedicel; 
scape appears subtly lighter than in $S$. beresfordi (S. beresfordi head, Fig. 2A).

Thorax: Indistinguishable from $S$. beresfordi (S. neglecta thorax, Figs. 4B, E, F).

Legs: Indistinguishable from $S$. beresfordi.

Wing: Costal vein covered in short setulae with one long black seta dorsal-basally.

Abdomen: Generally indistinguishable from $S$. beresfordi, although $S$. neglecta often tends to be a slightly lighter brown dorsally than $S$. beresfordi.

Terminalia; Slight lateral grove extends almost the entire length of more elongate surstylus (Fig. 5B); postgonite is somewhat more flattened, less scooping or cup posture than $S$. beresfordi (Fig. 5B).

Female: Similar to male except abdominal banding is somewhat lacking; abdomen terminates in long and slender ovipositor which closely resembles $S$. beresfordi (Fig. 2B); tergite 5 is about $5 \mathrm{~mm}$ long with anterior portion pale yellow, followed by darker brownish black, and abruptly terminating in paler yellow; majority of ovipositor with short, irregular setulae on dorsal surface only, becoming distinctly regular and forming thick band of black pile towards dark, anterior end of ovipositor, the pile becoming rather pale on distally palest area just before genitalia.

Terminalia: As in $S$. beresfordi except: cerci short, with very thick and long black spine-like setae, not extending to tip of hypoproct, setae sharply pointed (Fig. 4D).

Egg: Very similar to $S$. beresfordi. Only discernable difference is microsculptured surface (Fig. 4C) slightly more defined than $S$. beresfordi (Fig. 2D). Egg described in detail by Taber and Maloney (2006).

Hosts: Unknown.

Known distribution: Stylogaster neglecta ranges from Ontario and southern Québec, Canada, south to Georgia and west as far as mid Nebraska and Kansas, United States of America (Fig. 6B). Camras and Parrillo (1985) suggested that the range extended farther west to Arizona and farther south to Sinaloa and Chiapas, Mexico. This is undoubtedly due to the inclusion of specimens of our new species, S. beresfordi, within the former boundaries of $S$. neglecta.

Comments: Five COI sequences have been obtained and are published in GenBank (Table 1). The sequences were identical. Genetically and morphologically, this species is closest to $S$. beresfordi and is hypothesised to be its sister clade (Fig. 7).

\section{Acknowledgements}

Thanks to Scott Kelso for collecting some of the COI barcoding data and to the Canadian Centre for DNA Barcoding for sequencing other specimens and housing the data in BOLD. Victoria Nowell databased and geocoded all of the specimens examined. This work was supported by funding to J.H.S. from Agriculture and Agri-Food Canada and the Natural Sciences and Engineering Research Council of Canada. David Moll provided the field photographs of S. beresfordi (Figs. 1B, C). Jeff Cumming provided valuable advice that helped develop the approach to the project. Jens-Hermann Stuke and one anonymous reviewer provided useful comments on the manuscript and helped to improve the final product. L.R. provided insight into Neotropical Stylogaster and examined type material of most world species. He also provided guidance with character selection. T.O.B. and J.H.S. worked together equally on specimen examination, species concept formulation, and data organisation. T.O.B. took the lead in preparation of the manuscript and key and produced all of the drawings used in the paper. J.H.S. reworked and fleshed out the manuscript.

\section{References}

Aldrich, J.M. 1930. American two-winged flies of the genus Stylogaster Macquart. Proceedings of the United States National Museum, 78: 1-27.

Banks, N. 1912. At the Ceanothus in Virginia. Entomology News and the Proceedings of the Entomological Section of the Academy of Natural Sciences of Philadelphia, 23: 1-484.

Banks, N. 1916. Synopses of Zodion and Myopa with notes on other Conopidae. Annals of the Entomological Society of America, 9: 191-200.

Bequaert, J. 1922. The predaceous enemies of ants. Bulletin of the American Museum of Natural History, 45: 271-332.

Britton, W.E. 1920. Check-list of the insects of Connecticut. Bulletin of the Connecticut State Geological and Natural History Survey, 31: 1-397.

Camras, S. 1965. Family Conopidae. In A catalog of the Diptera of America north of Mexico. Edited by A. Stone, C.W. Sabrosky, W.W. Wirth, R.H. Foote, and J.R. Coulson. United States Department of Agriculture, Agricultural Research Service, Washington, District of Columbia, United States of America. Pp. 625-632.

Camras, S. 1967. Notes on Neotropical Stylogaster (Diptera: Conopidae). Journal of the Kansas Entomological Society, 40: 4-9. 
Camras, S. and Parrillo, P.P. 1985. Review of New World Stylogaster (Diptera: Conopidae). Annals of the Entomological Society of America, 78: 111-126.

Couri, M.S. and Pont, A.C. 2006. Eggs of Stylogaster Macquart (Diptera: Conopidae) on Madagascan muscids (Diptera: Muscidae). Proceedings of the California Academy of Sciences, 57: 473-478.

Couri, M.S. and Silva Barros, G.P.d. 2010. Diptera hosts of Stylogaster Macquart (Diptera, Conopidae) from Madagascar and South Africa. Revista Brasileira de Entomologia, 54: 361-366.

Cumming, J.M. and Wood, D.M. 2009. Adult morphology and terminology. In Manual of Central American Diptera. Edited by B.V. Brown, A. Borkent, J.M. Cumming, D.M. Wood, N.E. Woodley, and M.A. Zumbado. National Research Council Press, Ottawa, Ontario, Canada. Pp. 9-50.

Curran, C.H. 1942. American Diptera. Bulletin of the American Museum of Natural History, 80: 51-84.

Gibson, J.F. and Skevington, J.H. 2013. Phylogeny and taxonomic revision of all genera of Conopidae (Diptera) based on morphological data. Zoological Journal of the Linnaean Society, 167: 43-81.

Gibson, J.F., Skevington, J.H., and Kelso, S. 2013. A phylogenetic analysis of relationships among genera of Conopidae (Diptera) based on molecular and morphological data. Cladistics, 29: 193-226.

Greene, G.M. 1913. Secretarial report on Feldman collecting social. Entomology News and the Proceedings of the Entomological Section of the Academy of Natural Sciences of Philadelphia, 24: 45.

Johannsen, O.A. 1928. List of the insects of New York with a list of the spiders and certain other allied groups. Memoirs. Cornell University Agricultural Experment Station, 101: 687-869.

Johnson, C.W. 1910. Order Diptera. A report of the insects of New Jersey by J. B. Smith and others. Annual Report New Jersey State Museum, 1910: 703-814.

Johnson, C.W. 1913. Insects of Florida. I. Diptera. Bulletin of the American Museum of Natural History, 32: 37-90.

Johnson, C.W. 1925. Fauna of New England. 15. List of the Diptera or two-winged flies. Occasional Papers of the Boston Society of Natural History, 7: 1-326.

Jones, P.R. 1907. A preliminary list of the Conopidae of Nebraska. The Canadian Entomologist, 39: 250-251.

Kotrba, M. 1997. Shoot or stab? Morphological evidence on the unresolved oviposition technique in Stylogaster Macquart (Diptera: Conopidae), including discussion of behavioral observations. Proceedings of the Entomological Society of Washington, 99: 614-622.

Kröber, O. 1914. Das Genus Stylogaster Macqu. (Dipt.). Entomologische Mitteilungen, 3: 338-353.

Leonard, M.D. 1928. A list of insects of New York. Cornell University Agricultural Experiment Station, Ithaca, New York, United States of America. Pp. 1-1121.
Lopes, H.d.S. 1937. Contribuição ao conhecimento do genero "Stylogaster" Macquart 1835 (Dipt. Conopidae). Archivos do Instituto de Biologia Vegetal, 3: 257-293.

Macquart. 1843. Diptères exotiques nouxeaux ou peu connus. [Ier] Suplément. Mémoires de la Société royale des Sciences, de l'Agriculture et des Arts, Lille, 1844: 133-364.

Maddison, W.P. and Maddison, D.R. 2011. Mesquite: a modular system for evolutionary analysis. Version 2.75 [online]. Available from http://mesquiteproject. org [accessed 10 May 2014].

Miller, M.A., Pfeiffer, W., and Schwartz, T. 2010. Creating the CIPRES Science Gateway for inference of large phylogenetic trees. In Proceedings of the Gateway computing environments workshop (GCE). 14 November 2010, New Orleans, LA, Association for Computing Machinery, Institute of Electrical and Electronics Engineers (IEEE), New York, New York, United States of America. Pp. 1-8.

Osten Sacken, C.R. 1878. Catalogue of the described Diptera of North America. In Smithsonian Miscellaneous Collections. Volume 16, 2nd edition. Smithsonian Institute, Washington, DC, United States of America. Pp. 1-276.

Papavero, N. 1971. Family Conopidae. In A catalogue of the Diptera of the Americas south of the United States. Edited by N. Papavero. Museu de Zoologia, Universidade de São Paulo, São Paulo, Brazil. Pp. 1-28.

Posada, D. and Crandall, K.A. 1998. MODELTEST: testing the model of DNA substitution. Bioinformatics Applications Note, 14: 817-818.

Rettenmeyer, C.W. 1961. Observations on the biology and taxonomy of flies found over swarm raids of army ants (Diptera: Tachinidae, Conopidae). The University of Kansas Science Bulletin, 42: 993-1066.

Röder, V.V. 1892. Ueber die Dipteren-Gattung Stylogster Mcq. Wiener Entomologische Zeitung, 11: $286-288$.

Ronquist, F. and Huelsenbeck, J.P. 2003. MrBayes 3: Bayesian phylogenetic inference under mixed models. Bioinformatics Applications Note, 19: 1572-1574.

Say, T. 1823. Descriptions of dipterous insects. Academy of Natural Sciences of Philadelphia, 3: 73-104.

Skevington, J.H. and Thompson, F.C. 2012. Review of New World Sericomyia (Diptera: Syrphidae), including description of a new species. The Canadian Entomologist, 144: 216-247.

Smith, K.G.V. 1967. The biology and taxonomy of the genus Stylogaster Macquart, 1835 (Diptera: Conopidae, Stylogasterinae) in the Ethiopian and Malagassy regions. Transactions of the Royal Entomological Society of London, 119: 47-69.

Smith, K.G.V. and Cunningham-van Someren, G.R. 1985. The larva of Stylogaster varifrons Malloch (Diptera: Stylogastridae). Entomologists' Monthly Magazine, 121: 81-85. 
Smith, K.G.V. and Peterson, B.V. 1987. Conopidae. In Manual of Nearctic Diptera. Monograph No. 28. Volume 2. Edited by J.F. McAlpine, B.V. Peterson, G.E. Shewell, H.J. Teskey, J.R. Vockeroth, and D.M. Wood. Research Branch, Agriculture Canada, Ottawa, Ontario, Canada. Pp. 749-756.

Snow, F.H. 1903. A preliminary list of the Diptera of Kansas. The Kansas University Science Bulletin, 2: 211-221.

Stuke, J.-H. 2012. A revision of Afrotropical species of Stylogaster Macquart (Diptera: Conopidae), with descriptions of twenty-one new species and an identification key. African Invertebrates, 53: 267-354.

Swofford, D.L. 2001. PAUP*. Phylogenetic analysis using parsimony (*and other methods). Sinauer Associates Inc., Sunderland, Massachusetts, United States of America.

Taber, S.W. and Maloney, J.L. 2006. The egg of Stylogaster neglecta Williston (Diptera: Conopidae). The Great Lakes Entomologist, 39: 80-86.

Townsend, C.H.T. 1895. Contributions to the Dipterology of North America. II. Tabanidæ, Conopidae, Tachinidæ, etc. Transactions of the American Entomological Society, 22: 55-81.

Tucker, E.S. 1907. Some results of desultatory collecting of insects in Kansas and Colorado. Kansas University Science Bulletin, 4: 51-112.
Westwood, J.O. 1851. Observations on the destructive species of dipterous insects known in Africa under the names of the tsetse, zimb and tsaltsalya, and on their supposed connection with the fourth plague of Egypt. Proceedings of the Zoological Society of London, 18: 258-270.

Wiedemann, C.R.W. 1830. Aussereuropäische zweiflügeligen Insekten. Als Fortsetzung des Meigenschen Werkes. Zweiter Theil, 2: 1-684.

Williston, S.W. 1883. North American Conopidae: Stylogaster, Dalmannia, Oncomyia. Transcontinental Academy of Science, 6: 5-12.

Williston, S.W. 1885. North American Conopidae III: conclusion. Transactions. Volume 6, Connecticut Academy of Arts and Sciences, The Tuttle, Morehouse \& Taylor Company, New Haven, Connecticut. 377-394 + 371 plates.

Williston, S.W. 1893. Diptera Brasiliana. Part III. Kansas University Quarterly, 1: 119-122.

Williston, S.W. 1894. Bibliography of North American Dipterology 1878-1895. Kansas University Quarterly, 4: 129-144.

Williston, S.W. 1908. Manual of North American Diptera. 3rd edition. J.T. Hathaway New Haven, Connecticut, United States of America. Pp. 1-405.

Woodley, N.E. and Judd, D.D. 1998. Notes on the host, egg, and puparium of Stylogaster biannulata (Say) (Diptera: Conopidae). Proceedings of the Entomological Society Washington, 100: 658-664. 